\title{
Structural basis underlying strong interactions between ankyrins and spectrins
}

Jianchao $\mathrm{Li}^{1,2,5}$, Keyu Chen ${ }^{1,3,5, *}$, Ruichi Zhu ${ }^{1}$, and Mingjie Zhang ${ }^{1,3,4, *}$

$$
\begin{gathered}
{ }^{1} \text { Division of Life Science, State Key Laboratory of Molecular Neuroscience, Hong } \\
\text { Kong University of Science and Technology, Clear Water Bay, Kowloon, Hong } \\
\text { Kong, China. }
\end{gathered}
$$

${ }^{2}$ Division of Cell, Developmental and Integrative Biology, School of Medicine, South China University of Technology, Guangzhou 510006, China

${ }^{3}$ Greater Bay Biomedical Innocenter, Shenzhen Bay Laboratory, Shenzhen 518055, China ${ }^{4}$ Center of Systems Biology and Human Health, Hong Kong University of Science
and Technology, Clear Water Bay, Kowloon, Hong Kong, China.

Running title: Structures of ankyrin/spectrin complexes

${ }^{5}$ These authors contributed equally to this work.

*Correspondence: Keyu Chen (khenae@connect.ust.hk) and Mingjie Zhang (mzhang@ust.hk) 


\section{Abstract}

Ankyrins (encoded by ANK1/2/3 corresponding to Ankyrin-R/B/G or AnkR/B/G), via binding to spectrins, connect plasma membranes with actin cytoskeleton to maintain mechanical strengths and to modulate excitabilities of diverse cells such as neurons, muscle cells, and erythrocytes. Cellular and genetic evidences suggest that each isoform of ankyrins pairs with a specific $\beta$-spectrin in discrete subcellular membrane microdomains for distinct functions, though the molecular mechanisms underlying such ankyrin/ $\beta$-spectrin pairings are unknown. In this study, we discover that a conserved and short extension $\mathrm{N}$-terminal to the $\mathrm{ZU}_{\mathrm{N}}-\mathrm{ZU} 5_{\mathrm{C}}-\mathrm{UPA}$ tandem (exZZU) is critical for each ankyrin to bind to $\beta$-spectrins with high affinities. Structures of AnkB/G exZZU in complex with spectrin repeats13-15 of $\beta 2 / \beta 4$-spectrins solved here reveal that the extension sequence of exZZU forms an additional $\beta$-strand contributing to the structural stability and enhanced affinity of each ZU5N/spectrin repeat interaction. The junction site between the extension and $\mathrm{ZU}_{\mathrm{N}}$ is exactly the position of a splicing-mediated miniexon insertion site of $A n k B / G$. The complex structures further reveal that the UPA domain of exZZU directly participates in spectrin binding. Formation of the exZZU supramodule juxtaposes the $\mathrm{ZU} 5_{\mathrm{N}}$ and UPA domains for simultaneous interacting with spectrin repeats 14 and 15. However, our biochemical and structural investigations indicate that the direct and strong interactions between ankyrins and $\beta$-spectrins do not appear to determine their pairing specificities. Therefore, there likely exists additional mechanism(s) for modulating functional pairings between ankyrins and $\beta$-spectrins in cells. 


\section{Introduction}

Ankyrins and spectrins are key scaffold proteins in micron-scale membrane domains of excitable and mechano-resistant tissues/cells, such as the heart T-tubules in cardiomyocytes, the axon initial segment (AIS) and nodes of Ranvier (NOR) in neurons, the lateral membrane in epithelial cells, the sarcomeres in skeletal muscles and the plasma membrane in erythrocytes [1-3]. These specialized membrane domains clustered high density of ion channels, cell adhesion molecules and diverse signaling proteins to achieve their highly specialized functions. By anchoring and stabilizing numerous integral membrane proteins at specific membrane sites, ankyrin and spectrin complexes link these integral membrane proteins to the spectrin/actin based cytoskeletal networks, helping to organize and support these membrane micro-domains. Dysfunctions of ankyrin/spectrin complexes lead to malfunctions of membrane microdomains and cause many different types of human diseases. For example, a number of loss-of-function mutations in ankyrin-R (AnkR) and $\beta 1$-spectrin are known to cause hereditary spherocytosis [4-6]; genetic variants of ankyrin-G (AnkG) and ankyrin-B $($ AnkB) are associated with bipolar disorders [7-11], schizophrenia [12-14], autism spectrum disorders [15-22] and severe ataxia [23]; mutations in $\beta 3$-spectrin cause spinocerebellar ataxia type 5 (SCA5) [24-26]; alterations in $\beta 4$-spectrin cause spectrinopathy [27-29]; dysfunction of AnkB or $\beta 2$-spectrin can lead to serious cardiac pathologies, like inherited cardiac arrhythmia that known as the AnkB syndrome [3037].

Ankyrin family contains three members, AnkR, AnkB and AnkG, which are encoded by ANK1, ANK2 and ANK3 respectively. All three ankyrins share similar domain organizations (Figure 1A): a membrane-binding domain (MBD) located in the $\mathrm{N}$-terminus responsible for interacting with various membrane proteins [38], a spectrinbinding domain (SBD) following MBD, a linker region connecting MBD and SBD which is also capable of folding back to inhibit MBD/target interactions [39], an unstructured tail following SBD with extremely different lengths followed by a death domain, and a short C-terminal domain. The SBD is composed of three subdomains, 
ZU5N, ZU5C and UPA domain, forming a structural supramodule (ZZU) [40]. Spectrin family is composed of two groups of subunits: $\alpha$-spectrins and $\beta$-spectrins, each containing multiple continuous spectrin repeats. Under the plasma membrane of living cells, spectrins exist as tetramers, each formed by two $\alpha$ and two $\beta$ subunits. Vertebrates express two $\alpha$-spectrins ( $\alpha \mathrm{I}, \alpha \mathrm{II})$ and five $\beta$-spectrins ( $\beta 1, \beta 2, \beta 3, \beta 4$, and $\beta 5$ ). Their spectrin repeats endow spectrin tetramers with mechanical resilience [41-44]. Except for $\beta 5$-spectrin, all mammalian $\beta$-spectrins can bind to ankyrins through their middle spectrin repeats $[1,45]$.

A number of evidences imply that ankyrin and spectrin isoforms may have pairwise binding specificities at various subcellular microdomains. For example, AnkG specifically pairs with $\beta 2$-spectrin in the lateral membranes of epithelial cells; AnkB forms complex with $\beta 2$-spectrin throughout neuronal axons, whereas AnkG pairs specifically with $\beta 4$-spectrin in AIS and NOR in axons [2]. Another interesting observation is that when AnkG was knocked out from axon, AnkR together with $\beta 1$ spectrin instead of $\beta 4$-spectrin became to be enriched in NOR [46]. Reciprocally, the $\beta 1$-spectrin/AnkR pair instead of the $\beta 1$-spectrin/AnkG complex became clustered in NOR after removal of $\beta 4$-spectrin from neurons [46,47]. These observations suggest possible existence of specific pairings between isoforms of ankyrins and spectrins in living cells, though with totally unknown underlying molecular mechanisms.

Spectrins together with F-actin and some actin associated proteins like adducin form an elastic cytoskeleton network near the inner surface of plasma membranes. Ankyrins bind to integral membrane proteins (e.g. anion exchanger, L1CAM or Ecadherin) through their MBD and bind to $\beta$-spectrins through their SBD to connect plasma membranes to the elastic cytoskeleton thereby strengthening membrane lipid bilayers for mechanical stability. Interestingly, except for the ankyrin/spectrin interactions, the pairwise binding affinities between key components within this network are all quite strong with dissociation constants $(\mathrm{Kd}$, or half maximal concentration) of a few tens nanomoles (Figure S1). For example, the half maximal concentration of the spectrin/actin interaction is $~ 15-75 \mathrm{nM}$ [48], spectrin/adducin 
interaction is $\sim 80-100 \mathrm{nM}[49,50], \sim 60 \mathrm{nM}$ for the adducin and F-actin tip interaction [48], and $~ 10 \mathrm{nM}$ between $\alpha$ and $\beta$-spectrin [51]. Also, on the membrane-cytoskeleton interface, the Kd values of the ankyrin/anion exchanger complex is 10 $\mathrm{nM}$ [1] and the ankyrin/neurofascin is $\sim 50-500 \mathrm{nM}[1,39]$. These strong interactions presumably are fitting with the strong mechanostability roles of the ankyrin and spectrin/actin cytoskeleton assembly at the membrane microdomains. Curiously, the reported binding affinity between ankyrin and spectrin is $\sim 6.8 \mu \mathrm{M}$ [40], which is much weaker than the rest of the interactions in the network. Considering that ankyrin-spectrin interaction is the major linkage between the plasma membranes and the actin cytoskeleton of this network, the reported weak affinity between ankyrin and spectrin may not be able to support the stability of the network. Thus, we hypothesized that either the reported affinity on the ankyrin/spectrin interaction is incomplete or there are certain uncharacterized regulatory mechanisms for the ankyrin-spectrin interactions.

Although the ankyrin $\mathrm{ZU}_{\mathrm{N}}-\mathrm{ZU} 5_{\mathrm{C}}-\mathrm{UPA}$ tandem (ZZU) forms a compact supramodule [40], the bindings of ankyrins to spectrins seem to only require the first ZU5 domain $\left(\mathrm{ZU}_{\mathrm{N}}\right)$ of the tandem [52,53]. Here, we discovered that an extension sequence preceding the $\mathrm{ZU} 5_{\mathrm{N}}$ of the $\mathrm{ZZU}$ tandem of ankyrins can dramatically enhance their spectrin binding affinities. We solved the crystal structures of AnkB exZZU in complex with repeats 13-15 (R13-15) of $\beta 4$-spectrin and AnkG exZZU in complex with R13-15 of $\beta 2$-spectrin and with R13-15 of $\beta 4$-spectrin. These structures shed light on how the extension sequence in exZZU can enhance the interactions between ankyrins and spectrins. Our structures also reveal that, in addition to the $\mathrm{ZU} 5_{\mathrm{N}}$ domain, the UPA domain in the exZZU supramodule of ankyrins also directly contacts with spectrins. The biochemical and structural results presented in this study may serve as a foundation for understanding specific functional pairings between ankyrins and spectrins in living cells. 


\section{Results}

\section{A short extension $\mathrm{N}$-terminal to ZU5N enhances the ankyrin/spectrin interactions}

Amino acid sequence analysis discovered that a short stretch of residues immediately preceding the $\mathrm{ZU}{ }_{\mathrm{N}}$ domain of ankyrins are highly conserved during evolution and are very similar among AnkR/B/G (Figure 1A and 1B). Since the residues immediately following this extension (i.e. the $\beta 1$ strand of $Z \mathrm{Z}_{\mathrm{N}}$ ) are directly involved in binding to spectrins based on the structure of the AnkR ZU5 $5_{N}$ in complex with R1315 of $\beta 1$-spectrin [52] (PDB ID: 3KBT; Figure 1B), we speculated that this extension may participate in ankyrins' binding to spectrins. As in living cells, $\beta 2$-spectrin can bind to both AnkB and AnkG [2], we therefore chose $\beta 2$-spectrin as the representative $\beta$ spectrin to test our hypothesis. Interestingly, with this extension sequence (15 aa, boxed in pink in figure $1 \mathrm{~A} \& B$ ) appended to AnkB ZU5N-ZU5C-UPA (defined as exZZU, aa 951-1443), the binding affinity between $\beta 2$-spectrin and AnkB exZZU (Kd $~ 0.20 \mu M)$ is $>20$ folds stronger than that between $\beta 2$-spectrin and AnkB ZU5N-ZU5C-UPA-DD tandem (ZZUD) (aa 966-1535) (Kd values of $\sim 0.20 \mu \mathrm{M} v s \sim 4.9 \mu \mathrm{M}$; Figure 1C). Inclusion of additional N-terminal sequence as well as the death domain (i.e., an AnkB strong binding between AnkB and $\beta 2$-spectrin. Similarly, inclusion of this extension also enhanced AnkB's binding to $\beta 4$-spectrin (Figure S2B) and AnkG's binding to $\beta 2$ spectrin (Figure 1D). We have also investigated the role of the extension sequence in AnkB's binding to $\beta 1$-spectrin. Although AnkB is not known to pair with $\beta 1$-spectrin in living cells, the extension sequence also enhanced the binding between AnkB and $\beta 1$-spectrin by 12 folds (Figure S2C). Taken together, the above biochemical studies indicated that the extension sequence $\mathrm{N}$-terminal to the $\mathrm{ZU} 5_{\mathrm{N}}$ can enhance pairwise bindings between ankyrins and $\beta$-spectrins. Importantly, the $\mathrm{Kd}$ values between ankyrins and $\beta$-spectrins are in the range of tens to hundreds of nanomoles, matching with the rest of the strong pairwise interactions in the ankyrin/actin cytoskeleton networks shown in Figure S1. Our results further suggested that the interactions 
165 between various combinations of ankyrin and $\beta$-spectrin pairs all appear to be strong interactions (i.e. there appears no pairwise specificity code between specific pairs of ankyrins and $\beta$-spectrins observed in cells).

\section{Crystal structure of the $\beta 2-$ spectrin/AnkG exZZU complex}

To elucidate detailed mechanisms underlying the N-terminal extension-mediated enhancement of interactions between ankyrins and $\beta$-spectrins, we first crystalized $\beta 2$ spectrin repeat 13-15 in complex with AnkG exZZU (aa 975-1465) and solved the complex crystal structure at the resolution of $3.3 \AA$ (Table 1). Consistent with the apoform structure of the AnkB ZU5N-ZU5C-UPA tandem [40], the AnkG ZU5N-ZU5C-UPA tandem also forms a supramodule with a cloverleaf-like architecture (Figure 2A), suggesting the formation of the ZZU supramodule is a common feature shared by all three ankyrin family members. The R13-R15 repeats of $\beta 2$-spectrin contacts with the surfaces of ZU5 ${ }_{\mathrm{N}}$ and UPA. The interface between $\beta 2$-spectrin R14 and AnkG ZU5 $5_{\mathrm{N}}$ is nearly identical to that between $\beta 1$-spectrin R14 and AnkR ZU5N as shown in the structure of $\beta 1$-spectrin R13-15 in complex with the solo ZU5N of AnkR (Figure S3) [52]. Although the ZZU supramodule provides a larger spectrin binding interface, R13 of $\beta 2$-spectrin is not involved in the AnkG binding. This is consistent with our biochemical result showing that deleting R13 does not impair ankyrin/ $\beta$-spectrin interaction (Figure S2A).

Guided by the AnkG/ $\beta 2$-spectrin complex structure, we were able to optimize construct boundaries of the AnkB/ $\beta 4$-spectrin and $A n k G / \beta 4$-spectrin complexes for crystallizations and solved the structures of these two complexes at resolutions of 3.4 $\AA ̊$ and $4.3 \AA$, respectively (Figure 2B-E and Table 1). The overall architectures of the three pairs of ankyrin exZZU/B-spectrin R13-15 structures are essentially the same, including the cloverleaf-like ZU5N-ZU5C-UPA supramodule and the main $Z{ }^{2} 5_{N} / \beta$ spectrin R14 interface. The orientations of R13 and R15 with respect to R14 in three structures are slightly different (Figure 2B), which is not surprising given that the 
conformations between spectrin repeats are known to be partially elastic in spectrins [41-44].

\section{Structural basis for the enhanced spectrin binding by the $\mathrm{N}$-terminal extension of ankyrins}

Based on the three complex structures, we analyzed how the N-extension can enhance ankyrin's binding to $\beta$-spectrin. When building the structure models, we observed clear electron densities N-terminal to F992 in AnkG or F968 in AnkB (Figure 2C and 3D). These electron densities correspond to the residues from the $\mathrm{N}$-terminal extension. For the AnkG/ $\beta 2$-spectrin and AnkB/ $\beta 4$-spectrin structures, an additional $\beta$ strand was modeled and denoted as $\beta 0$ corresponding to the $\mathrm{N}$-terminal extension for each ankyrin exZZU (Figure 2C and 2D). The low resolution of the AnkG/ $\beta 4$-spectrin structure did not allow us to confidently build the atomic model, but obvious electron densities in the difference map also indicate the formation of $\beta 0$ in the exZU5 $5_{N}$ in AnkG when in complex with $\beta 4$-spectrin (Figure 2E).

Surprisingly, there is no direct contact between $\beta$-spectrin and $Z \mathrm{ZU}_{\mathrm{N}} \beta 0$ in both AnkG//2-spectrin and AnkB/ $\beta 4$-spectrin complex structures. We hypothesized that the enhanced binding might be due to the stabilization of $\mathrm{ZU} 5_{\mathrm{N}}$ by the additional $\beta$ strand (i.e. $\beta 0$ ) formed by the $\mathrm{N}$-terminal extension. The $\beta 0$ strand is anti-parallelly paired with $\beta 1$, making $\mathrm{ZU}_{\mathrm{N}}$ a 13 -stranded $\beta$-barrel (Figure $3 \mathrm{~A}$ ). Two hydrophobic residues in the extension sequence (I964 and F968 in AnkB exZZU, V986 and F992 in AnkG exZZU; Figure 1B) insert into the hydrophobic core of ZU5N, which should stabilize the folding of the ZU5 domain. Nonetheless, these two residues are not absolutely required for the overall folding of the remaining $12 \beta$ strands of $Z \mathrm{ZU}_{\mathrm{N}}$ as $\mathrm{I} 964$ is missing and side-chain of F968 is facing outside (i.e. exposed to solvent) in the previous solved apo-AnkB ZZUD structure (PDB ID: 4D8O). Substitution of F968 by alanine decreased the AnkB exZZU/ $\beta 2$-spectrin binding by more than ten folds (Figure 3D). Similarly, replacing I964 by a polar glutamine also weakened the binding by about four-fold (Figure 3E). 
The above biochemical and structural analysis suggested that, by forming an additional $\beta$ strand, the $\mathrm{N}$-terminal extension can stabilize the $\mathrm{ZU} 5_{\mathrm{N}}$ structure and consequently enhance the bindings of ankyrin exZZU to $\beta 2$-spectrin.

\section{The UPA domain is also involved in the ankyrin-spectrin interaction}

Another new finding from the three complex structures solved in this study is that the UPA domain of ankyrin exZZU directly participates in binding to $\beta$-spectrin. By superimposing the UPA domains' structures from the AnkB exZZU/ $\beta 4$-spectrin complex and from the apo-AnkB ZZU structure (Figure 3B), we could observe an obvious shift and rotation of the $\alpha 1$ helix. Such shift and rotation facilitate a few direct polar interaction between residues from $\alpha 1$ of UPA and R14 of $\beta$-spectrin. For example, T1324 and Q1328 on AnkB exZZUD form hydrogen bonds with D1773 and D1755 on $\beta 4$-spectrin repeat 14 , respectively. K1320 in the loop preceding $\alpha 1$ of UPA also forms a salt bridge with D1773 from $\beta 4$-spectrin. Consistent with the above structural analysis, substitution of T1324 in $\alpha 1$ of UPA with Asp reduced the interaction between AnkB exZZU and $\beta 4$-spectrin by about five-fold (Figure 3F).

\section{The exZZU supramodule of ankyrins functions as an integral unit for binding to}

\section{$\beta$-spectrin}

The finding that both the $\mathrm{ZU} 5_{\mathrm{N}}$ and UPA domains of ankyrins are directly involved in binding to $\beta$-spectrins prompted us to propose that the overall conformation (i.e. the tertiary structure) of the exZZU supramodule is important for ankyrin-spectrin interactions (Figure 4A). Our previous [40] and currently solved structures revealed that R1029 from AnkB ZU5N is critical for the ZU5N/UPA coupling by forming salt bridges with a negatively charged residue (D1319 as revealed by the previous AnkB ZZUD structure or D1318 as revealed by the structure solved here) from UPA domain (Figure 4B). The residues corresponding to R1029 and D1318/1319 are completely conserved in all isoforms of ankyrins throughout the evolution (see Figure 2 in Wang 
et al., 2012 for detailed sequence alignment analysis). We replaced R1029 of AnkB with

Glu to destabilize the ZU5N/UPA coupling in the exZZU supramodule. The R1029E mutation reduced AnkB exZZU's binding to $\beta 2$-spectrin by $\sim 5$ folds (Figure $4 \mathrm{C}$ and 4D). The above biochemical and structural analyses suggest that the $\mathrm{ZU} 5_{\mathrm{N}} / \mathrm{UPA}$ coupling stabilizes the tertiary structure of the ankyrin exZZU supramodule, which is required for the high affinity interactions between ankyrins and $\beta$-spectrins.

\section{Discussion}

In this study, we identified a short and evolutionally conserved sequence immediately preceding the $\mathrm{ZU} 5_{\mathrm{N}}$ domain of $\mathrm{AnkB}$ and AnkG. It can significantly enhance the binding between AnkB/AnkG and $\beta$-spectrins. We demonstrated that the binding affinities between AnkB/AnkG and $\beta$-spectrins are in similar range as those very strong pairwise bindings between the ankyrin/actin cytoskeleton network components, which are critical for stable membrane micro-domain assemblies (Figure S1; [1,39,48-51]). The structures of AnkB/AnkG exZZU in complex with R13-15 of $\beta 2 / \beta 4$-spectrins illustrate that the $\mathrm{N}$-terminal extension stabilizes the $\mathrm{ZU}{ }_{\mathrm{N}}$ domain structure by forming an additional $\beta$ strand and thus enhances $\beta$-spectrin binding. The structures of the ankyrin/spectrin complexes solved in this study further reveal that the UPA domain of ankyrins directly participates in binding to $\beta$-spectrin. We provided biochemical evidence to show that the tertiary structural arrangement of the exZZU supramodule is important for the interactions between ankyrins and $\beta$-spectrins, implying that long-range conformational perturbations may regulate ankyrin/ $\beta$-spectrin interactions. This tertiary structural requirement of ankyrin exZZU for binding to $\beta$ spectrin may provide a possible explanation to why certain disease mutations in the exZZU supramodule may alter ankyrin’s binding to $\beta$-spectrin, even if such mutation sites are away from the $\beta$-spectrin binding surface. interaction in AIS during neuronal development [54-56]. The splicing factor Rbfox or 
Elavl3 can regulate the insertion of a mini-exon coding extra 11 amino acid residues into the site between the extension sequence and the canonical $\mathrm{ZU} 5_{\mathrm{N}}$ domain in both AnkG and AnkB (see Figure 1B for the insertion site). For AnkG splicing isoform containing this mini-exon, the binding of AnkG to $\beta 2$ - or $\beta 4$-spectrin is largely decreased as demonstrated by immunoprecipitation experiments [54]. This result is in line with our structural and biochemical data presented in this study. The insertion of the 11-residue fragment encoded by the mini-exon is expected to disrupt the $\beta 0$ strand formed by the N-terminal extension sequence in AnkG (and in AnkB and AnkR as well) and thereby decrease the binding affinity between AnkG and $\beta 2-/ \beta 4-$ spectrin. Thus, in addition to directly enhancing the interactions between ankyrins and spectrins, the $\mathrm{N}$ terminal extension of the ankyrin exZZU supramodule also serves as a splicingmediated switch for modulating their interactions.

A surprising and unexpected finding from the current structural and biochemical study is that AnkB and AnkG use very similar binding mode to interact with different $\beta$-spectrins and with comparable affinities (Figure 1 and Figure S2). This finding suggests that the specific pairings between isoforms of ankyrins and $\beta$-spectrins observed in distinct membrane microdomains of living cells are not solely determined by the high affinity interactions between the exZZU of ankyrins and R13-15 of $\beta$ spectrins. There should be certain additional mechanism(s) that can modulate specific pairings between ankyrins and $\beta$-spectrins. Supporting this speculation, a recent study showed that the giant insertion encoded by a single exon coding $>3000$ amino acid residues in $480-\mathrm{kDa}$ AnkG is essential for the recruitment of $\beta 4$-spectrin to AIS [57]. Further studies will be required to understand the detailed mechanisms underlying the specific pairings between ankyrins and $\beta$-spectrins.

\section{Materials and methods}

\section{Constructs, protein expression and purification}


All of the AnkB constructs coding sequences were PCR amplified from the fulllength human 220-kDa AnkB cDNA plasmid (residue numbers referred to NP_001341186.1). All of the AnkG constructs were originated from a rat 270-kDa cDNA (residue numbers according to GenBank ID: AAC78143.1). Both of the AnkB and AnkG template plasmids are gifts from Dr. Vann Bennett at Duke University. $\beta$ spectrins' coding sequences were PCR amplified from mouse brain or muscle cDNA libraries. The corresponding residue numbers of different spectrin repeats are summarized in Table 2. All point mutations were generated by the Quick Change sitedirected mutagenesis kit (Agilent, CA) and confirmed by DNA sequencing. All of these coding sequences were cloned into home-modified pET32a vectors for protein expression.

Recombinant proteins were purified as previously described [39]. In brief, $200 \mathrm{ng}$ plasmids were transformed into $50 \mu \mathrm{L}$ Escherichia coli. BL21 (DE3) (New England Biolabs) competent cells. On the second day, the cells were inoculated to 1-2 L Lysogeny broth medium and incubated at $37{ }^{\circ} \mathrm{C}$ with shaking at $200 \mathrm{rpm}$. When UV absorbance at $600 \mathrm{~nm}$ of the cultured cells reached 0.8 , the cells were induced by adding $0.25 \mathrm{mM}$ IPTG and the culture was shifted to $16{ }^{\circ} \mathrm{C}$ for 20 hours with shaking at 200 rpm. The cells were then pelleted by centrifugation at 3,000 g for 15 minutes, resuspended with $40 \mathrm{~mL}$ resuspension buffer (50 mM Tris, $500 \mathrm{mM} \mathrm{NaCl,} 5 \mathrm{mM}$ imidazole, $\mathrm{pH}$ 8.0), and lysed by a high pressure homogenizer machine at $4^{\circ} \mathrm{C}$, followed by high speed centrifugation at 39,000 g for 20 minutes. The supernatant was injected into a $\mathrm{Ni}^{2+}$-NTA agarose affinity column (containing $5 \mathrm{~mL} \mathrm{Ni}^{2+}$-Sepharose $6 \mathrm{FF}$ beads, GE Healthcare, Cat. 17531803). The column was incubated for 15 minutes and washed twice with $30 \mathrm{~mL}$ washing buffer (50 mM Tris, $500 \mathrm{mM} \mathrm{NaCl,} 15 \mathrm{mM}$ imidazole, $\mathrm{pH}$ 8.0). Then the proteins on the column were eluted by $15 \mathrm{~mL}$ elution buffer ( $50 \mathrm{mM}$ Tris, $500 \mathrm{mM} \mathrm{NaCl}, 1 \mathrm{M}$ imidazole, $\mathrm{pH}$ 8.0). The eluted proteins were applied to a sizeexclusion column (HiLoad 26/600 Superdex 200 pg column from GE Healthcare) with the buffer containing 50 mM Tris-HCl, 1 mM DTT, and 1 mM EDTA, pH 7.8 with 100 $\mathrm{mM} \mathrm{NaCl}$. The fused Trx-His 6 tag was cleaved by incubating each recombinant protein 
with HRV 3C protease overnight at $4{ }^{\circ} \mathrm{C}$. The cleaved tag of each protein was removed by another step of the size exclusion chromatography.

\section{Isothermal Titration Calorimetry (ITC) assay}

Isothermal titration calorimetry (ITC) measurements were performed on a VP-ITC Microcal calorimeter (MicroCal, Northampton, MA) at $25{ }^{\circ} \mathrm{C}$. All purified protein samples were in reaction buffer containing $50 \mathrm{mM}$ Tris, $100 \mathrm{mM} \mathrm{NaCl,} 1 \mathrm{mM}$ EDTA and $1 \mathrm{mM}$ DTT at pH 7.5. Spectrin proteins in the concentrations of 100-200 $\mu \mathrm{M}$ were loaded into the syringe and ankyrin proteins in the concentrations of $10-20 \mu \mathrm{M}$ were loaded into the sample cell of the machine. Each titration point was performed by injecting a $10 \mu \mathrm{L}$ aliquot (the first titration point is $5 \mu \mathrm{L}$ ) of syringe protein into corresponding ankyrin protein samples in the cell at a time interval of 120 seconds. The titration data were analyzed using the program Origin7.0 and fitted by the one-site binding model.

\section{Crystallography}

All crystals were obtained by hanging drop or sitting drop vapor diffusion methods at $16^{\circ} \mathrm{C}$. Crystals of AnkG exZZU/ $\beta 2$-spectrin R13-R15 were grown in solution containing $10 \% \mathrm{w} / \mathrm{v}$ polyethylene glycol 6,000, 5\% v/v (+/-)-2-methyl-2,4-pentanediol and 0.1 M HEPES pH 7.5. Crystals of AnkB exZZU/ß4-spectrin R13-R15 were grown in solution containing 25\% w/v pentaerythritol propoxylate 629 (17/8 PO/OH), $50 \mathrm{mM}$ magnesium chloride and 0.1 M HEPES, pH 7.5. Crystals of AnkG exZZU/ß4-spectrin R13-R15 were grown in solution containing $0.8 \mathrm{M}$ potassium sodium tartrate tetrahydrate, $0.1 \mathrm{M}$ Tris, $\mathrm{pH} 8.5$ and $0.5 \% \mathrm{w} / \mathrm{v}$ polyethylene glycol monomethyl ether 5,000. Crystals were soaked in crystallization solution containing additional $20 \%$ glycerol for cryoprotection. All datasets were collected at the Shanghai Synchrotron Radiation Facility (BL17U1 or BL19U1) at $100 \mathrm{~K}$. Data were processed and scaled using HKL2000 or HKL3000 [58] . 

ZZU (PDB: 4D8O) and $\beta 1$-spectrin R13-R15 (PDB: 3KBT) as the searching models. Further manual model adjustment and refinement were completed iteratively using COOT [60] and PHENIX [61]. The final models were validated by MolProbity [63] and statistics are summarized in Table 1. All structure figures were prepared by PyMOL (http://www.pymol.org). The coordinates of the structures reported in this work are being deposited to PDB.

\section{Acknowledgements}

We thank the Shanghai Synchrotron Radiation Facility (SSRF) BL19U1 and BL17U1 for X-ray beam time. This work was supported by grants from RGC of Hong Kong (16100517 and 16104518) and from Natural Science Foundation of Guangdong

375 Province (2016A030312016) and Shenzhen Basic Research Grant (JCYJ20160229153100269). M.Z. is a Kerry Holdings Professor in Science and a 
bioRxiv preprint doi: https://doi org/101101/2020.03.04 976142; this version posted March 4,2020 . The copyright holder for this preprint (which was not certified by peer review) is the author/funder, who has granted bioRxiv a license to display the preprint in perpetuity. It is made available under aCC-BY-NC-ND 4.0 International license.

Table 1: Statistics of X-ray Crystallographic Data Collection and Model refinement

\begin{tabular}{|c|c|c|c|}
\hline \multicolumn{4}{|l|}{ Data collection } \\
\hline Dataset & AnkG/ß2-spectrin & AnkB/ $\beta 4$-spectrin & AnkG/ß4-spectrin \\
\hline Space group & $P 1$ & $P 2_{1} 2_{1} 2_{1}$ & $P 3_{2} 21$ \\
\hline Unit cell (a, b, c, Å) & $\begin{array}{l}\text { 66.277, 66.305, } \\
160.926\end{array}$ & $\begin{array}{l}\text { 70.900, 110.485, } \\
131.675\end{array}$ & $\begin{array}{l}\text { 139.591, 139.591, } \\
211.317\end{array}$ \\
\hline Unit cell $\left(\alpha, \beta, \gamma,{ }^{\circ}\right)$ & $\begin{array}{l}\text { 99.47, 99.78, } \\
100.87\end{array}$ & 90, 90, 90 & $90,90,120$ \\
\hline Wavelength $(\AA)$ & 0.9785 & 0.9780 & 0.9785 \\
\hline Resolution range ( $\AA$ ) & $\begin{array}{l}50.00-3.30 \\
(3.36-3.30)\end{array}$ & $\begin{array}{l}50.00-3.40 \\
(3.46-3.40)\end{array}$ & $\begin{array}{l}50.00-4.30 \\
(4.37-4.30)\end{array}$ \\
\hline No. of unique reflections & 37513 (1815) & $14141(686)$ & $16538(805)$ \\
\hline Redundancy & $2.8(2.5)$ & $6.7(6.2)$ & $15.7(16.1)$ \\
\hline $\mathrm{I} / \sigma$ & $5.7(0.5)$ & $9.4(2.9)$ & $14.0(1.0)$ \\
\hline Completeness (\%) & $97.7(97.7)$ & 99.5 (98.4) & $99.9(100.0)$ \\
\hline $\mathrm{R}_{\text {merge }}(\%)^{\mathrm{a}}$ & $11.2(>100)$ & 25.5 (76.7) & $15.9(>100)$ \\
\hline $\begin{array}{l}\text { CC1/2 for highest } \\
\text { resolution shell }{ }^{\text {b }}\end{array}$ & 0.566 & 0.661 & 0.510 \\
\hline \multicolumn{4}{|l|}{ Structure refinement } \\
\hline Resolution $(\AA)$ & $\begin{array}{l}50.0-3.30 \\
(3.41-3.30)\end{array}$ & $\begin{array}{l}50.0-3.40 \\
(3.70-3.40)\end{array}$ & $\begin{array}{l}50.0-4.30 \\
(4.65-4.30)\end{array}$ \\
\hline $\mathrm{R}_{\text {cryst }}{ }^{\mathrm{c}} / \mathrm{R}_{\text {free }}{ }^{\mathrm{d}}$ & $\begin{array}{l}0.2557(0.3877) / \\
0.2977(0.3993)\end{array}$ & $\begin{array}{l}0.2522(0.3098) / \\
0.3071(0.3624)\end{array}$ & $\begin{array}{l}0.2564(0.3291) / \\
0.2952(0.3806)\end{array}$ \\
\hline Rmsd bonds $(\AA) /$ angles $\left({ }^{\circ}\right)$ & $0.011 / 0.985$ & $0.005 / 1.064$ & $0.008 / 1.310$ \\
\hline Average B factor $\left(\AA^{2}\right)^{\mathrm{e}}$ & 108.3 & 63.2 & 87.7 \\
\hline No. of protein atoms & 10215 & 5446 & 5000 \\
\hline No. of other atoms & 0 & 0 & 0 \\
\hline No. of reflections & & & \\
\hline Working set & 35002 (2343) & 13389 (2455) & 15019 (2557) \\
\hline Test set & $1723(145)$ & $667(124)$ & $763(133)$ \\
\hline Ramachandran plot (\%) ${ }^{\mathrm{e}}$ & & & \\
\hline Favored regions & 95.4 & 95.7 & 90.1 \\
\hline Allowed regions & 4.3 & 3.8 & 9.7 \\
\hline Outliers & 0.3 & 0.5 & 0.2 \\
\hline
\end{tabular}

Numbers in parentheses represent the value for the highest resolution shell.

a. $\mathrm{R}_{\text {merge }}=\Sigma \mid I_{i}-\langle I>| / \Sigma I_{i}$, where $I_{i}$ is the intensity of measured reflection and $\langle I>$ is the mean intensity of all symmetry-related reflections.

b. $\mathrm{CC}_{1 / 2}$ were defined by Karplus and Diederichs [63].

c. $\mathrm{R}_{\text {cryst }}=\Sigma|| F_{\text {calc }}|-| F_{\text {obs }} \mid / \Sigma F_{\text {obs }}$, where $F_{\text {obs }}$ and $F_{\text {calc }}$ are observed and calculated structure factors.

d. $R_{\text {free }}=\Sigma_{\mathrm{T}}|| F_{\text {calc }}|-| F_{\text {obs }}|| / \Sigma F_{\text {obs }}$, where $\mathrm{T}$ is a test data set of about $5 \%$ of the total unique reflections randomly chosen and set aside prior to refinement.

e. B factors and Ramachandran plot statistics are calculated using MOLPROBITY [62]. 
bioRxiv preprint doi: https://doi.org/10.1101/2020.03.04.976142; this version posted March 4, 2020. The copyright holder for this preprint (which was not certified by peer review) is the author/funder, who has granted bioRxiv a license to display the preprint in perpetuity. It is made available under aCC-BY-NC-ND 4.0 International license.

389 Table 2: Summary of $\beta$-spectrin constructs' boundaries

\begin{tabular}{cccc}
\hline Species & Spectrin & Spectrin Repeats & Residue Number \\
\hline \multirow{2}{*}{ mouse } & $\beta 1$-spectrin & $13-16$ & $1583-2010$ \\
& NP_038703.3 & & \\
mouse & $\beta 2$-spectrin & $13-15$ & $1591-1904$ \\
& NP_787030.2 & $13-16$ & $1591-2018$ \\
& & $14-15$ & $1694-1904$ \\
mouse & $\beta 4-$-spectrin & $13-15$ & $1611-1932$ \\
& AAK38731.1 & $13-16$ & $1611-2040$ \\
& & $14-15$ & $1714-1932$ \\
\hline
\end{tabular}




\section{References}

391 1. Bennett V, Healy J (2009) Membrane Domains Based on Ankyrin and Spectrin Associated with Cell-Cell Interactions. Cold Spring Harb Perspect Biol 1: a003012-a003012.

2. Bennett V, Lorenzo DN (2013) Spectrin- and Ankyrin-Based Membrane Domains and the Evolution of Vertebrates. In Bennett V (ed.), Current Topics in Membranes pp 1-37. Academic Press.

3. Bennett V, Lorenzo DN (2016) Chapter Five - An Adaptable Spectrin/Ankyrin-Based Mechanism for Long-Range Organization of Plasma Membranes in Vertebrate Tissues. In Bennett V (ed.), Current Topics in Membranes pp 143-184. Academic Press.

4. Da Costa L, Galimand J, Fenneteau O, Mohandas N (2013) Hereditary spherocytosis, elliptocytosis, and other red cell membrane disorders. Blood Rev 27: 167-178.

5. Eber SW, Gonzalez JM, Lux ML, Scarpa AL, Tse WT, Dornwell M, Herbers J, Kugler W, Ozcan R, Pekrun A, et al. (1996) Ankyrin-1 mutations are a major cause of dominant and recessive hereditary spherocytosis. Nat Genet 13: 214-218.

6. Lux SE, Tse WT, Menninger JC, John KM, Harris P, Shalev O, Chilcote RR, Marchesi SL, Watkins PC, Bennett V, et al. (1990) Hereditary spherocytosis associated with deletion of human erythrocyte ankyrin gene on chromosome 8. Nature 345: 736-739.

7. Ferreira MAR, O’Donovan MC, Meng YA, Jones IR, Ruderfer DM, Jones L, Fan J, Kirov G, Perlis RH, Green EK, et al. (2008) Collaborative genome-wide association analysis supports a role for ANK3 and CACNA1C in bipolar disorder. Nat Genet 40: 1056-1058.

8. Schulze TG, Detera-Wadleigh SD, Akula N, Gupta A, Kassem L, Steele J, Pearl J, Strohmaier J, Breuer R, Schwarz M, et al. (2009) Two variants in Ankyrin 3 (ANK3) are independent genetic risk factors for bipolar disorder. Mol Psychiatry 14: 487-491.

9. Chen DT, Jiang X, Akula N, Shugart YY, Wendland JR, Steele CJM, Kassem L, Park J-H, Chatterjee N, Jamain S, et al. (2013) Genome-wide association study meta-analysis of European and Asian-ancestry samples identifies three novel loci associated with bipolar disorder. Mol Psychiatry 18: 195-205.

10. Mühleisen TW, Leber M, Schulze TG, Strohmaier J, Degenhardt F, Treutlein J, Mattheisen M, Forstner AJ, Schumacher J, Breuer R, et al. (2014) Genome-wide association study reveals two new risk loci for bipolar disorder. Nat Commun 5: 3339.

11. Zhu S, Cordner ZA, Xiong J, Chiu C-T, Artola A, Zuo Y, Nelson AD, Kim T-Y, Zaika N, Woolums BM, et al. (2017) Genetic disruption of ankyrin-G in adult mouse forebrain causes cortical synapse alteration and behavior reminiscent of bipolar disorder. Proc Natl Acad Sci 114: 10479-10484.

12. Ripke S, Sanders AR, Kendler KS, Levinson DF, Sklar P, Holmans PA, Lin D-Y, Duan J, Ophoff RA, Andreassen OA, et al. (2011) Genome-wide association study identifies five new schizophrenia loci. Nat Genet 43: 969-976.

13. Nie F, Wang X, Zhao P, Yang H, Zhu W, Zhao Y, Chen B, Valenzuela RK, Zhang R, Gallitano AL, et al. (2015) Genetic analysis of SNPs in CACNA1C and ANK3 gene with schizophrenia: A comprehensive meta-analysis. Am J Med Genet B Neuropsychiatr Genet 168: 637-648.

14. Guo X, Zhang Y, Du J, Yang H, Ma Y, Li J, Yan M, Jin T, Liu X (2016) Association analysis of ANK3 gene variants with schizophrenia in a northern Chinese Han population. Oncotarget 7: 85888-85894. 
15. Iqbal Z, Vandeweyer G, Voet M van der, Waryah AM, Zahoor MY, Besseling JA, Roca LT, Silfhout ATV, Nijhof B, Kramer JM, et al. (2013) Homozygous and heterozygous disruptions of ANK3: at the crossroads of neurodevelopmental and psychiatric disorders. Hum Mol Genet 22: $1960-1970$.

16. Willsey AJ, Sanders SJ, Li M, Dong S, Tebbenkamp AT, Muhle RA, Reilly SK, Lin L, Fertuzinhos S, Miller JA, et al. (2013) Coexpression Networks Implicate Human Midfetal Deep Cortical Projection Neurons in the Pathogenesis of Autism. Cell 155: 997-1007.

17. Parikshak NN, Luo R, Zhang A, Won H, Lowe JK, Chandran V, Horvath S, Geschwind DH (2013) Integrative Functional Genomic Analyses Implicate Specific Molecular Pathways and Circuits in Autism. Cell 155: 1008-1021.

18. Shi L, Zhang X, Golhar R, Otieno FG, He M, Hou C, Kim C, Keating B, Lyon GJ, Wang K, et al. (2013) Whole-genome sequencing in an autism multiplex family. Mol Autism 4: 8.

19. Iossifov I, O'Roak BJ, Sanders SJ, Ronemus M, Krumm N, Levy D, Stessman HA, Witherspoon K, Vives L, Patterson KE, et al. (2014) The contribution of de novo coding mutations to autism spectrum disorder. Nature 515: 216-221.

20. De Rubeis S, He X, Goldberg AP, Poultney CS, Samocha K, Ercument Cicek A, Kou Y, Liu L, Fromer M, Walker S, et al. (2014) Synaptic, transcriptional and chromatin genes disrupted in autism. Nature 515: 209-215.

21. Kloth K, Denecke J, Hempel M, Johannsen J, Strom TM, Kubisch C, Lessel D (2017) First de novo ANK3 nonsense mutation in a boy with intellectual disability, speech impairment and autistic features. Eur J Med Genet.

22. Yang R, Walder-Christensen KK, Kim N, Wu D, Lorenzo DN, Badea A, Jiang Y-H, Yin HH, Wetsel WC, Bennett V (2019) ANK2 autism mutation targeting giant ankyrin-B promotes axon branching and ectopic connectivity. Proc Natl Acad Sci 116: 15262-15271.

23. Zhou D, Lambert S, Malen PL, Carpenter S, Boland LM, Bennett V (1998) AnkyrinG Is Required for Clustering of Voltage-gated Na Channels at Axon Initial Segments and for Normal Action Potential Firing. J Cell Biol 143: 1295-1304.

24. Ikeda Y, Dick KA, Weatherspoon MR, Gincel D, Armbrust KR, Dalton JC, Stevanin G, Dürr A, Zühlke C, Bürk K, et al. (2006) Spectrin mutations cause spinocerebellar ataxia type 5. Nat Genet 38: 184-190.

25. Lise S, Clarkson Y, Perkins E, Kwasniewska A, Akha ES, Schnekenberg RP, Suminaite D, Hope J, Baker I, Gregory L, et al. (2012) Recessive Mutations in SPTBN2 Implicate $\beta$-III Spectrin in Both Cognitive and Motor Development. PLOS Genet 8: e1003074.

26. Parolin Schnekenberg R, Perkins EM, Miller JW, Davies WIL, D’Adamo MC, Pessia M, Fawcett KA, Sims D, Gillard E, Hudspith K, et al. (2015) De novo point mutations in patients diagnosed with ataxic cerebral palsy. Brain J Neurol 138: 1817-1832.

27. Knierim E, Gill E, Seifert F, Morales-Gonzalez S, Unudurthi SD, Hund TJ, Stenzel W, Schuelke M (2017) A recessive mutation in beta-IV-spectrin (SPTBN4) associates with congenital myopathy, neuropathy, and central deafness. Hum Genet 136: 903-910.

28. Wang C-C, Ortiz-González XR, Yum SW, Gill SM, White A, Kelter E, Seaver LH, Lee S, Wiley G, Gaffney PM, et al. (2018) BIV Spectrinopathies Cause Profound Intellectual Disability, Congenital Hypotonia, and Motor Axonal Neuropathy. Am J Hum Genet 102: 1158-1168.

29. Liu C-H, Rasband MN (2019) Axonal Spectrins: Nanoscale Organization, Functional 
Domains and Spectrinopathies. Front Cell Neurosci 13:.

30. El Refaey MM, Mohler PJ (2017) Ankyrins and Spectrins in Cardiovascular Biology and Disease. Front Physiol 8: 852.

31. Mohler PJ, Schott J-J, Gramolini AO, Dilly KW, Guatimosim S, duBell WH, Song L-S, Haurogné K, Kyndt F, Ali ME, et al. (2003) Ankyrin-B mutation causes type 4 long-QT cardiac arrhythmia and sudden cardiac death. Nature 421: 634-639.

32. Scouarnec SL, Bhasin N, Vieyres C, Hund TJ, Cunha SR, Koval O, Marionneau C, Chen B, Wu Y, Demolombe S, et al. (2008) Dysfunction in ankyrin-B-dependent ion channel and transporter targeting causes human sinus node disease. Proc Natl Acad Sci 105: 15617-15622.

33. Sucharski HC, Dudley EK, Keith CBR, El Refaey M, Koenig SN, Mohler PJ (2020) Mechanisms and Alterations of Cardiac Ion Channels Leading to Disease: Role of Ankyrin-B in Cardiac Function. Biomolecules 10: 211.

34. Smith SA, Sturm AC, Curran J, Kline CF, Little SC, Bonilla IM, Long VP, Makara M, Polina I, Hughes LD, et al. (2015) Dysfunction in the $\beta I I$ spectrin-dependent cytoskeleton underlies human arrhythmia. Circulation 131: 695-708.

35. Smith SA, Hughes LD, Kline CF, Kempton AN, Dorn LE, Curran J, Makara M, Webb TR, Wright P, Voigt N, et al. (2016) Dysfunction of the $\beta 2$-spectrin-based pathway in human heart failure. Am J Physiol Heart Circ Physiol 310: H1583-1591.

36. Derbala MH, Guo AS, Mohler PJ, Smith SA (2018) The role of $\beta I I$ spectrin in cardiac health and disease. Life Sci 192: 278-285.

37. Hund TJ, Unudurthi SD, Greer-Short A, Patel N, Nassal D (2018) Spectrin-based pathways underlying electrical and mechanical dysfunction in cardiac disease. Expert Rev Cardiovasc Ther 16: 59-65.

38. Wang C, Wei Z, Chen K, Ye F, Yu C, Bennett V, Zhang M (2014) Structural basis of diverse membrane target recognitions by ankyrins. eLife 3: e04353.

39. Chen K, Li J, Wang C, Wei Z, Zhang M (2017) Autoinhibition of ankyrin-B/G membrane target bindings by intrinsically disordered segments from the tail regions. eLife 6: e29150.

40. Wang C, Yu C, Ye F, Wei Z, Zhang M (2012) Structure of the ZU5-ZU5-UPA-DD tandem of ankyrin-B reveals interaction surfaces necessary for ankyrin function. Proc Natl Acad Sci 109: 4822-4827.

41. Altmann SM, Grünberg RG, Lenne P-F, Ylänne J, Raae A, Herbert K, Saraste M, Nilges M, Hörber JKH (2002) Pathways and Intermediates in Forced Unfolding of Spectrin Repeats. Structure 10: 1085-1096.

42. Mirijanian DT, Voth GA (2008) Unique elastic properties of the spectrin tetramer as revealed by multiscale coarse-grained modeling. Proc Natl Acad Sci 105: 1204-1208.

43. Zhu Q, Asaro RJ (2008) Spectrin Folding versus Unfolding Reactions and RBC Membrane Stiffness. Biophys J 94: 2529-2545.

44. Renn JP, Bhattacharyya S, Bai H, He C, Li H, Oberhauser AF, Marko JF, Makarov DE, Matouschek A (2019) Mechanical unfolding of spectrin reveals a super-exponential dependence of unfolding rate on force. Sci Rep 9: 1-13.

45. Stabach PR, Morrow JS (2000) Identification and characterization of beta V spectrin, a mammalian ortholog of Drosophila beta H spectrin. J Biol Chem 275: 21385-21395.

46. Ho TS-Y, Zollinger DR, Chang K-J, Xu M, Cooper EC, Stankewich MC, Bennett V, Rasband MN (2014) A hierarchy of ankyrin-spectrin complexes clusters sodium channels at nodes of 
Ranvier. Nat Neurosci 17: 1664-1672.

47. Liu C-H, Stevens SR, Teliska LH, Stankewich M, Mohler PJ, Hund TJ, Rasband MN (2020) Nodal $\beta$ spectrins are required to maintain $\mathrm{Na}+$ channel clustering and axon integrity. eLife $\mathbf{9}$ : e52378.

48. Li X, Matsuoka Y, Bennett V (1998) Adducin Preferentially Recruits Spectrin to the Fast Growing Ends of Actin Filaments in a Complex Requiring the MARCKS-related Domain and a Newly Defined Oligomerization Domain. J Biol Chem 273: 19329-19338.

49. Gardner K, Bennett V (1987) Modulation of spectrin-actin assembly by erythrocyte adducin. Nature 328: 359-362.

50. Mische SM, Mooseker MS, Morrow JS (1987) Erythrocyte adducin: a calmodulin-regulated actin-bundling protein that stimulates spectrin-actin binding. J Cell Biol 105: 2837-2845.

51. Davis L, Lux SE, Bennett V (1989) Mapping the ankyrin-binding site of the human erythrocyte anion exchanger. J Biol Chem 264: 9665-9672.

52. Ipsaro JJ, Mondragón A (2010) Structural basis for spectrin recognition by ankyrin. Blood 115: 4093-4101.

53. Yasunaga M, Ipsaro JJ, Mondragón A (2012) Structurally Similar but Functionally Diverse ZU5 Domains in Human Erythrocyte Ankyrin. J Mol Biol 417: 336-350.

54. Jacko M, Weyn-Vanhentenryck SM, Smerdon JW, Yan R, Feng H, Williams DJ, Pai J, Xu K, Wichterle H, Zhang C (2018) Rbfox Splicing Factors Promote Neuronal Maturation and Axon Initial Segment Assembly. Neuron.

55. Ogawa Y, Yamaguchi J, Yano M, Uchiyama Y, Okano HJ (2018) Elavl3 regulates neuronal polarity through the alternative splicing of an embryo-specific exon in AnkyrinG. Neurosci Res.

56. Iijima T, Yoshimura T (2019) A Perspective on the Role of Dynamic Alternative RNA Splicing in the Development, Specification, and Function of Axon Initial Segment. Front Mol Neurosci 12:.

57. Yang R, Walder-Christensen KK, Lalani S, Yan H, García-Prieto ID, Álvarez S, FernándezJaén A, Speltz L, Jiang Y-H, Bennett V (2019) Neurodevelopmental mutation of giant ankyrinG disrupts a core mechanism for axon initial segment assembly. Proc Natl Acad Sci 201909989.

58. Otwinowski Z, Minor W (1997) Processing of X-ray diffraction data collected in oscillation mode. Methods Enzymol 276: 307-326.

59. McCoy AJ, Grosse-Kunstleve RW, Adams PD, Winn MD, Storoni LC, Read RJ (2007) Phaser crystallographic software. J Appl Crystallogr 40: 658-674.

60. Emsley P, Lohkamp B, Scott WG, Cowtan K (2010) Features and development of Coot. Acta Crystallogr D Biol Crystallogr 66: 486-501.

61. Adams PD, Afonine PV, Bunkóczi G, Chen VB, Davis IW, Echols N, Headd JJ, Hung L-W, Kapral GJ, Grosse-Kunstleve RW, et al. (2010) PHENIX: a comprehensive Python-based system for macromolecular structure solution. Acta Crystallogr D Biol Crystallogr 66: 213221.

62. Chen VB, Arendall WB, Headd JJ, Keedy DA, Immormino RM, Kapral GJ, Murray LW, Richardson JS, Richardson DC (2010) MolProbity: all-atom structure validation for macromolecular crystallography. Acta Crystallogr D Biol Crystallogr 66: 12-21.

63. Karplus PA, Diederichs K (2012) Linking crystallographic model and data quality. Science 
bioRxiv preprint doi: https://doi.org/10.1101/2020.03.04.976142; this version posted March 4, 2020. The copyright holder for this preprint (which was not certified by peer review) is the author/funder, who has granted bioRxiv a license to display the preprint in perpetuity. It is made available under aCC-BY-NC-ND 4.0 International license.

336: 1030-1033.

566 


\section{Figure legends:}

Figure 1: A conserved extension sequence is required for strong ankyrin/ $\beta$-spectrin interactions

571 (A) Schematic diagram showing the domain organizations of AnkR/B/G.

(B) Amino acid sequence alignment showing the conserved extension sequence $\mathrm{N}$ terminal to ZU5N among mouse AnkR, human AnkB and rat AnkG. “*”, “:”and “.” indicate fully conserved, highly conserved, and conserved residues, respectively.

(C) ITC results showing that AnkB exZZU binding to $\beta 2$-spectrin R13-15 is over 20fold stronger than AnkB ZZUD without the extension.

(D) ITC results showing that AnkG exZZUD binding to $\beta 2$-spectrin R13-16 is over 10fold stronger than AnkG ZZUD without the extension

Figure 2: Overall structure of AnkG exZZU/B2-spectrin R13-15 complex and common features revealed by the three complex structures.

(A) Ribbons diagram representation (left \& right top) and combined ribbon and surface representations (right bottom) of the crystal structure of AnkG exZZU/ $\beta 2$ spectrin R13-15. ZU5N (blue), ZU5C (cyan), UPA (green), and $\beta 2$-spectrin (gold) are drawn in their specific colors and this color code is used throughout the manuscript except as otherwise indicated.

(B) Superposition of all the three structures showing that the binding modes are very similar. In this superposition, $\mathrm{ZU}_{\mathrm{N}}$ was used as the reference for the structural alignment.

(C-E) Omit maps showing the formation of a $\beta$ strand by the extension in AnkG/ $\beta 2$ -

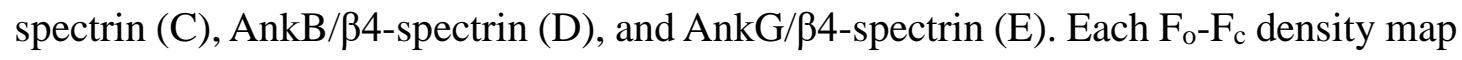
was generated by deleting the extension sequence from the final model and contoured at $2.5 \sigma$. 
597 (A) The additional $\beta 0$ formed by the extension packs to the ZU5N domain mainly

598 through hydrophobic interactions. The $\mathrm{ZU}_{\mathrm{N}}$ of the apo AnkB ZZUD structure is

599 colored in pink.

600 (B) UPA domain is involved in the interaction by hydrogen bonding. The UPA domain 601 of the apo AnkB ZZUD structure is colored in pink.

602 (C-F) ITC results showing that mutating the key residues in the interface between AnkB 603 exZZU and $\beta 4$-spectrin weakened the binding.

604

605 Figure 4: ZZU supramodule as an integral unit to bind to $\beta$-spectrin.

606 (A) R1029 (the red sphere) is located in the ZU5N/UPA interface.

607 (B) R1029 is critical for the ZU5N/UPA coupling by forming a salt bridge with D1318.

608 (C-D) A charge reversal mutation of R1029 decreased the binding between AnkB 609 exZZU and $\beta 2$-spectrin.

610 


\section{Supplemental Figure Legend}

613 Figure S1: Schematics showing the layered arrangement of the membrane614 ankyrin-spectrin network and affinities of interactions between key components.

615 Ankyrin with its MBD, SBD and DD is shown in light blue; $\alpha \beta$-spectrin heterotetramers

616 are represented by light purple columns; adducin is shown in yellow and actin is shown

617 in light green. Table in the bottom shows literature reported binding affinities

618 (dissociation constants or half maximal concentrations) between key components. “ “_”

619 means not determined in this study.

620

621 Figure S2: ITC data showing different AnkB constructs binding to $\beta 2-$ (A) or $\beta 4-$

622 (B) or $\beta 1$-spectrin (C).

623

Figure S3: Structure alignment of the $\beta 1$-spectrin/AnkR complex and the $\beta 2$ spectrin/AnkG complex.

626 The AnkR ZU5N domain is shown in pink and $\beta 1$-spectrin is shown in grey (PDB ID:

627 3KBT). The AnkG ZU5N domain is shown in blue and $\beta 2$-spectrin shown in gold. For 628 simplicity, the ZU5c and UPA domains are not drawn. 
bioRxiv preprint doi: https://doi.org/10.1101/2020.03 .04.976142; this version posted March 4,2020 . The copyright holder for this preprint (which was not certified by peer review) is the author/funder, who has granted bioRxiv a license to display the preprint in perpetuity. It is made available under aCC-BY-NC-ND 4.0 International license.

\section{Figure 1}

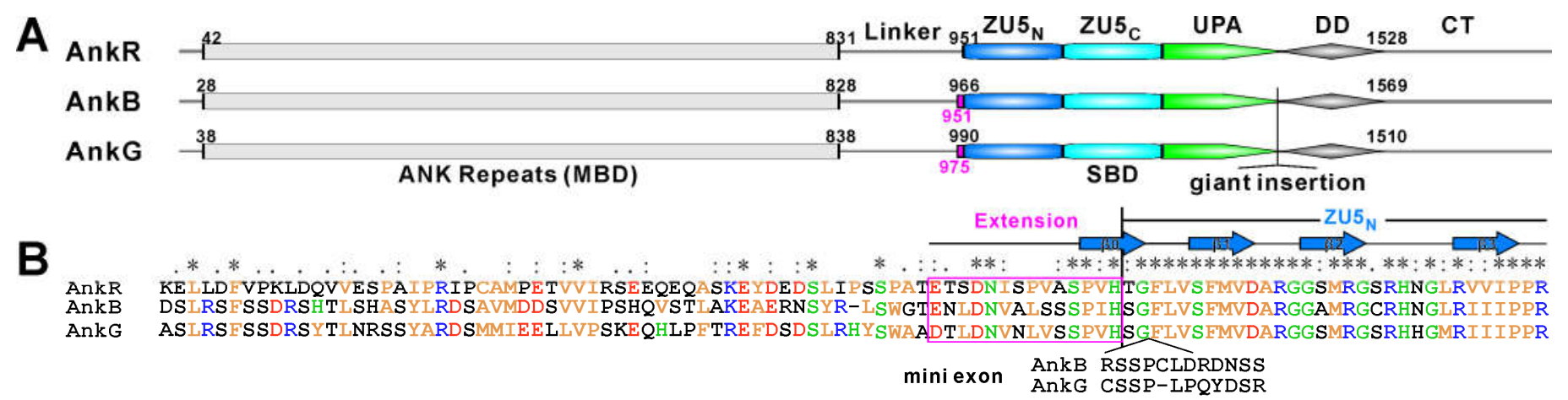

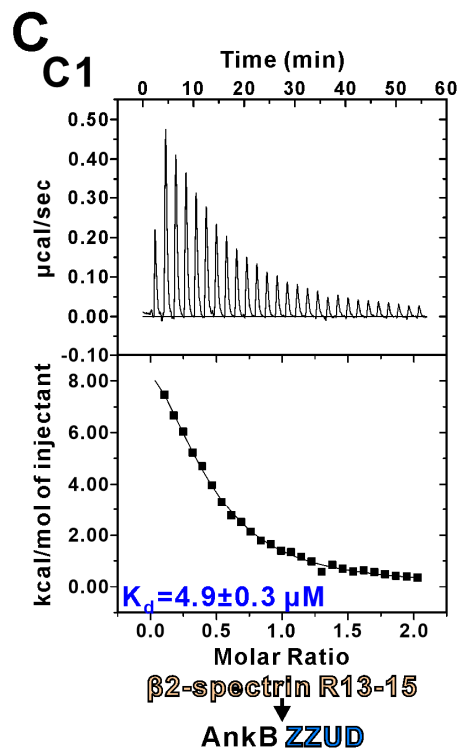

$\Delta \mathrm{H}=13.0 \pm 0.6 \mathrm{kcal} / \mathrm{mol}$ $\Delta \mathrm{S}=67.8 \mathrm{cal} /(\mathrm{mol} \cdot \mathrm{K})$

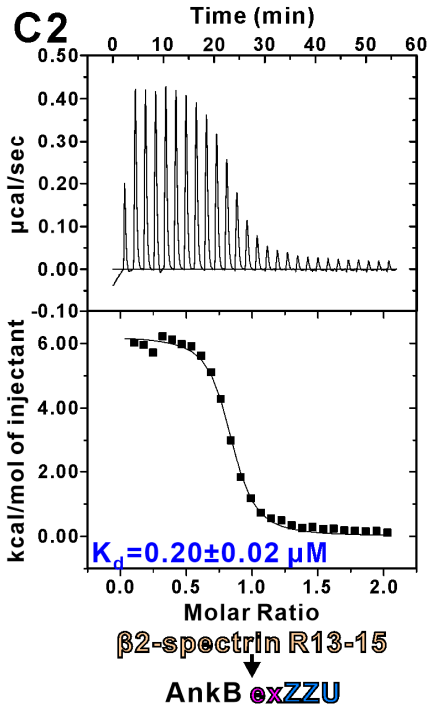

$\Delta \mathrm{H}=6.23 \pm 0.07 \mathrm{kcal} / \mathrm{mol}$ $\Delta \mathrm{S}=51.6 \mathrm{cal} /(\mathrm{mol} \cdot \mathrm{K})$

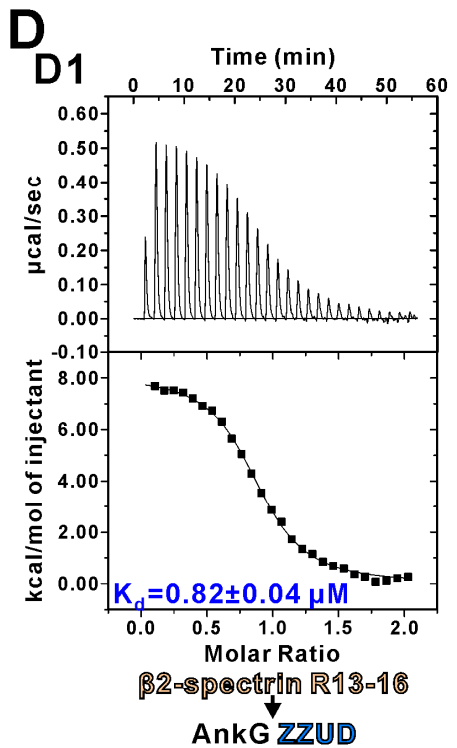

$\Delta \mathrm{H}=8.10 \pm 0.06 \mathrm{kcal} / \mathrm{mol}$

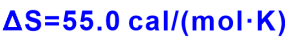

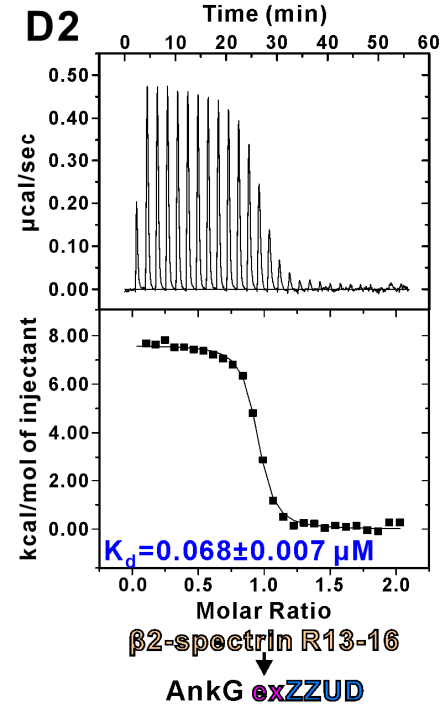

$\Delta \mathrm{H}=7.60 \pm 0.05 \mathrm{kcal} / \mathrm{mol}$ $\Delta \mathrm{S}=58.3 \mathrm{cal} /(\mathrm{mol} \cdot \mathrm{K})$ 
bioRxiv preprint doi: https://doi.org/10.1101/2020.03 04 976142; this version posted March 4,2020 . The copyright holder for this preprint (which was not certified by peer review) is the author/funder, who has granted bioRxiv a license to display the preprint in perpetuity. It is made available under aCC-BY-NC-ND 4.0 International license.

\section{Figure 2}

A

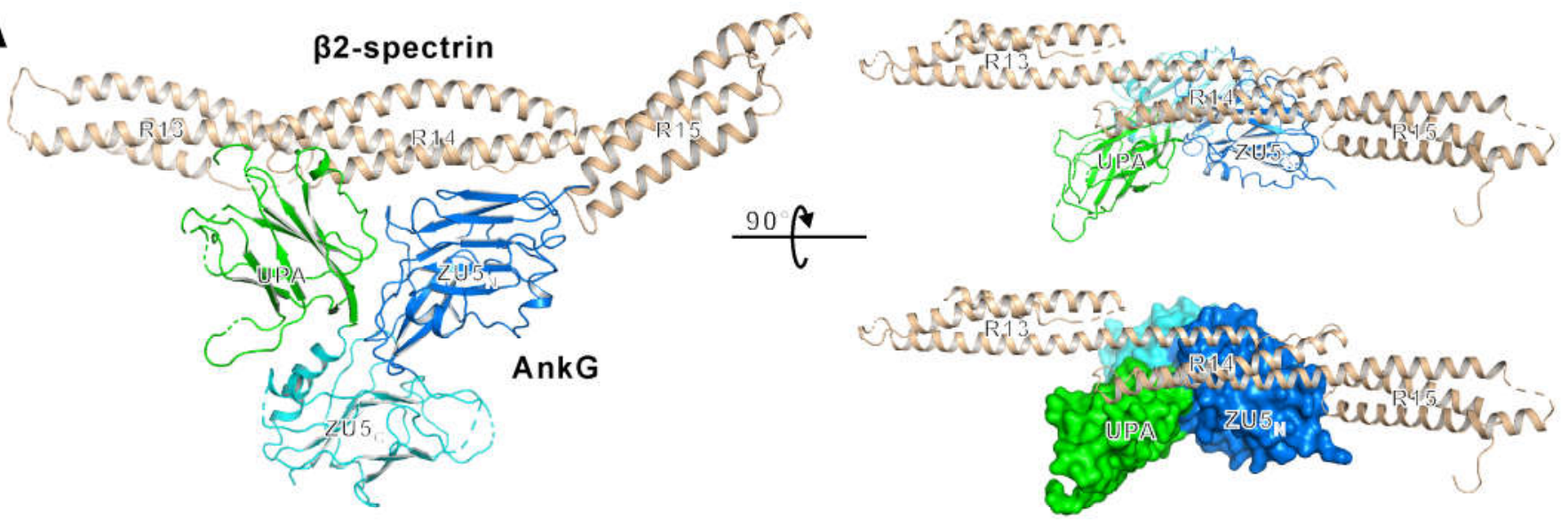

B

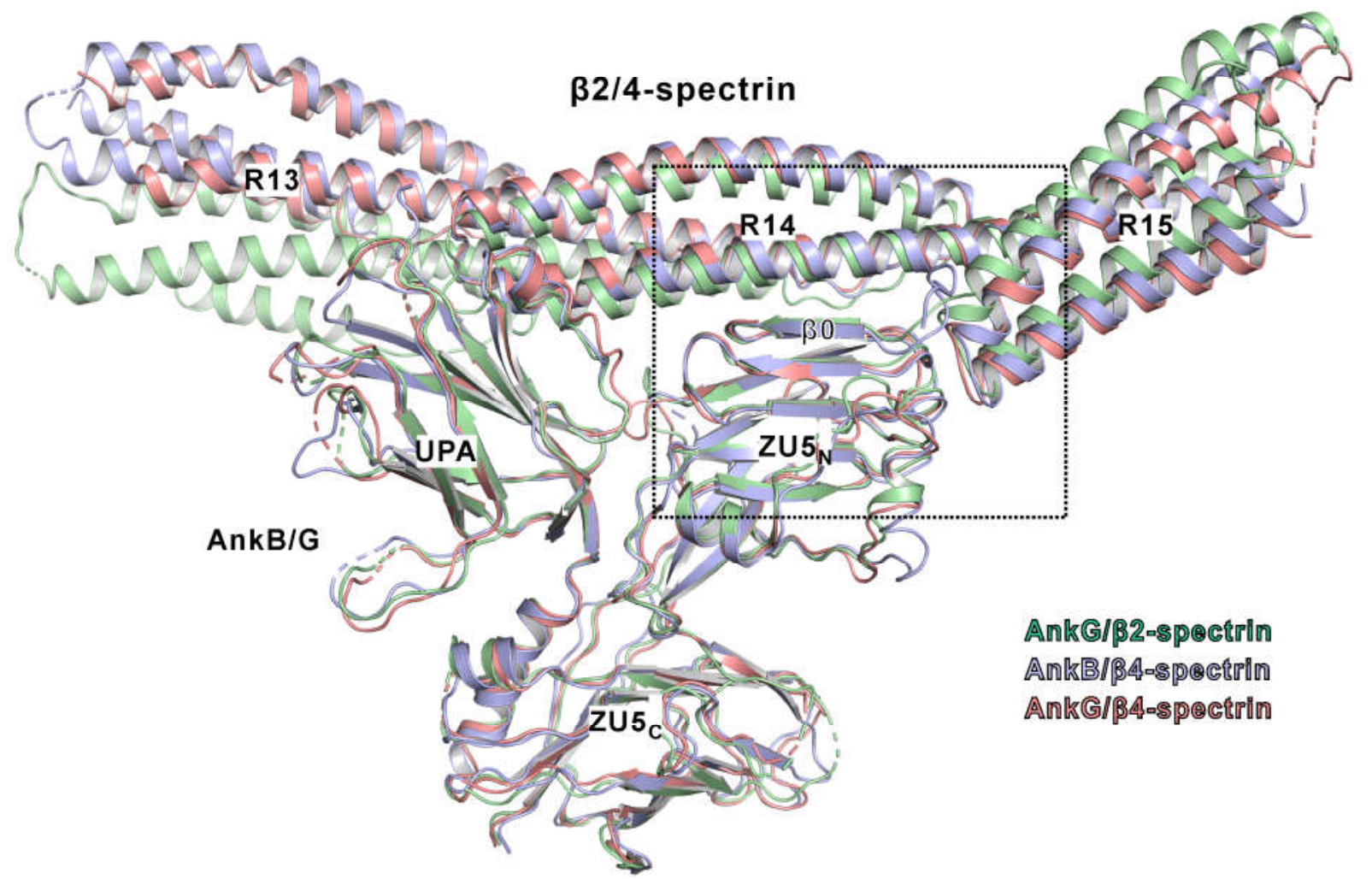

C

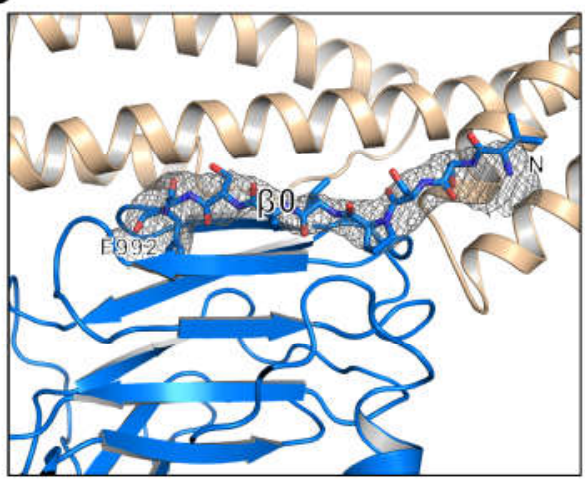

AnkG/ß2-spectrin
D

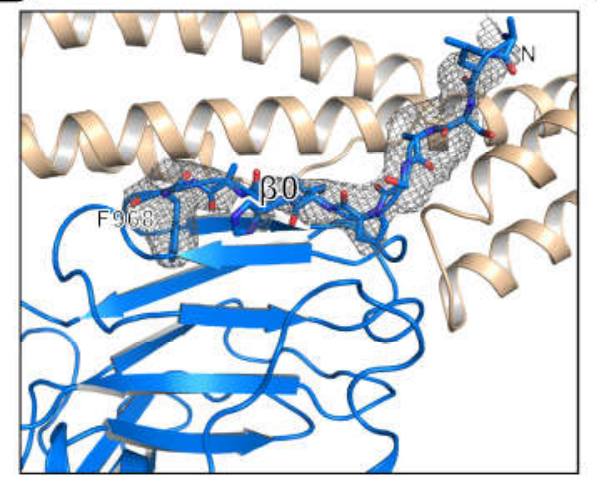

AnkB/B4-spectrin
E

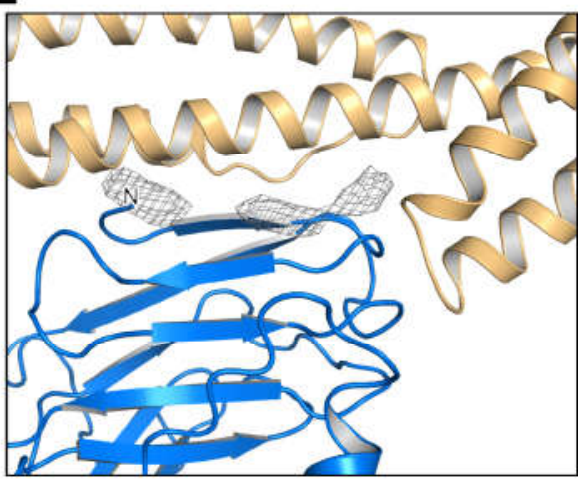

AnkG/B4-spectrin 
bioRxiv preprint doi: https://doi.org/10.1101/2020.03.04.976142; this version posted March 4, 2020. The copyright holder for this preprint (which was not certified by peer review) is the author/funder, who has granted bioRxiv a license to display the preprint in perpetuity. It is made available under aCC-BY-NC-ND 4.0 International license.

\section{Figure 3}

A

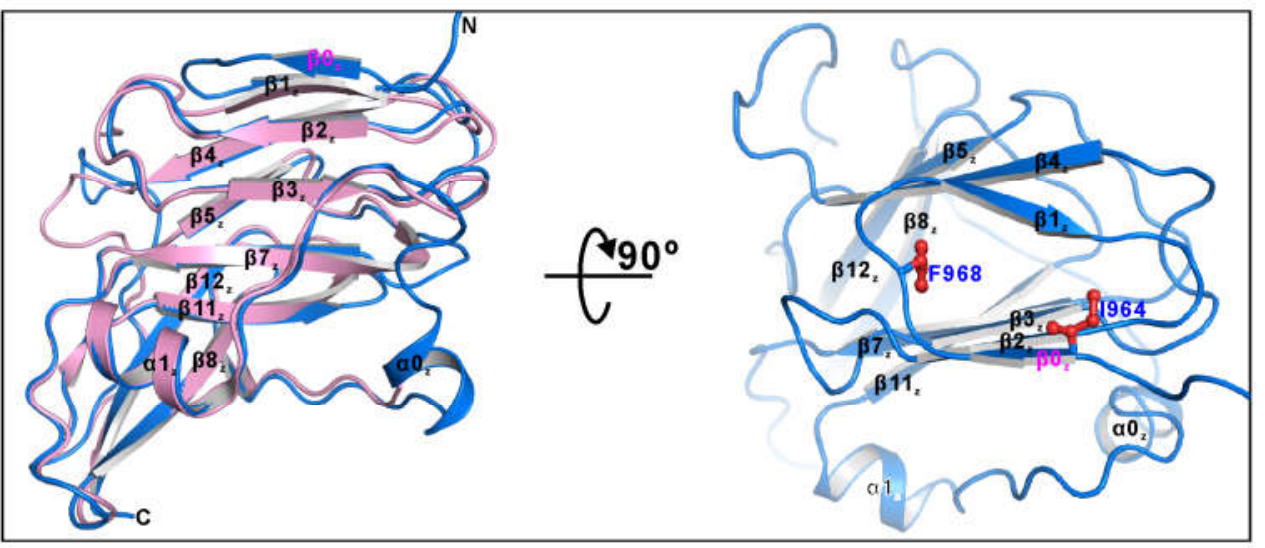

B

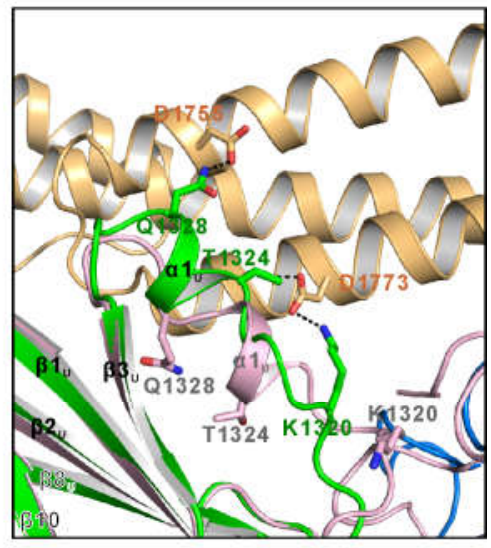

$\mathbf{F}$
C

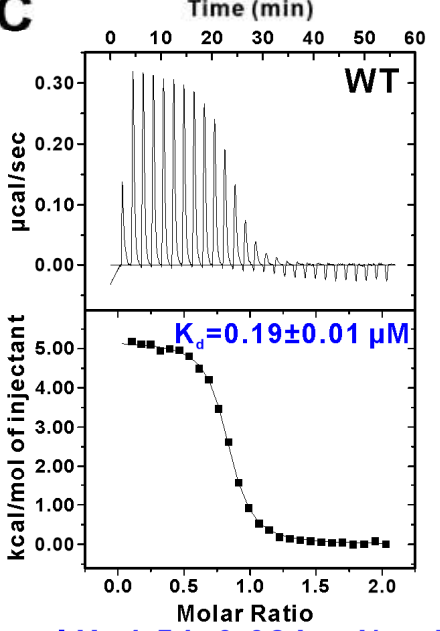

$\Delta \mathrm{H}=4.54 \pm 0.02 \mathrm{kcal} / \mathrm{mol}$ $\Delta \mathrm{S}=46.0 \mathrm{cal} /(\mathrm{mol} \cdot \mathrm{K})$
D

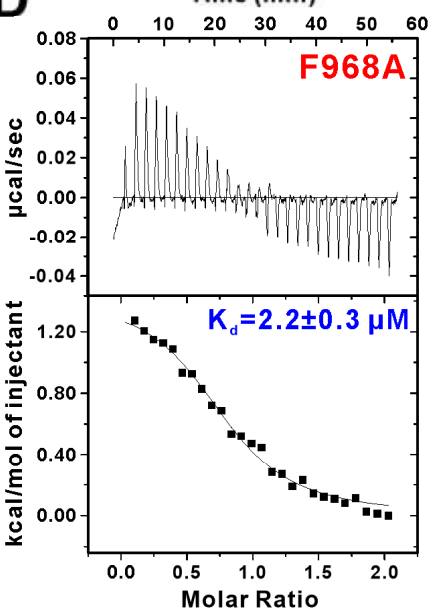

$\Delta \mathrm{H}=1.44 \pm 0.05 \mathrm{kcal} / \mathrm{mol}$ $\Delta \mathrm{S}=30.7 \mathrm{cal} /(\mathrm{mol} \cdot \mathrm{K})$
$E$

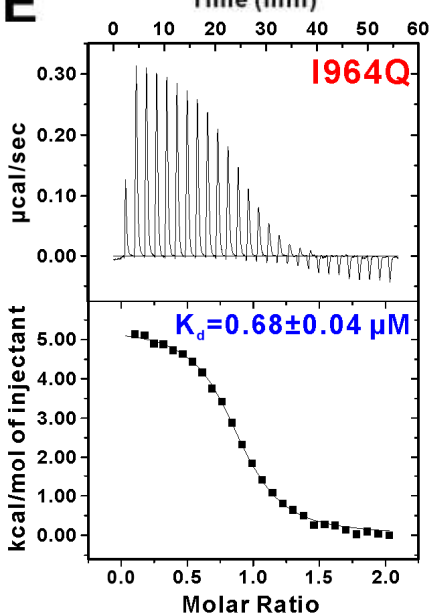

$\Delta \mathrm{H}=5.30 \pm 0.04 \mathrm{kcal} / \mathrm{mol}$ $\Delta \mathrm{S}=46.0 \mathrm{cal} /(\mathrm{mol} \cdot \mathrm{K})$

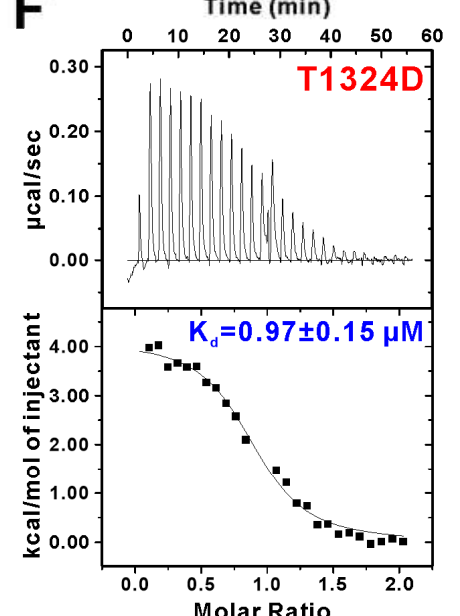

$\Delta \mathrm{H}=4.12 \pm 0.10 \mathrm{kcal} / \mathrm{mol}$ $\Delta \mathrm{S}=41.3 \mathrm{cal} /(\mathrm{mol} \cdot \mathrm{K})$ 
bioRxiv preprint doi: https://doi.org/10.1101/2020.03.04 976142; this version posted March 4,2020 . The copyright holder for this preprint (which was not certified by peer review) is the author/funder, who has granted bioRxiv a license to display the preprint in perpetuity. It is made available under aCC-BY-NC-ND 4.0 International license.

\section{Figure 4}

A

B

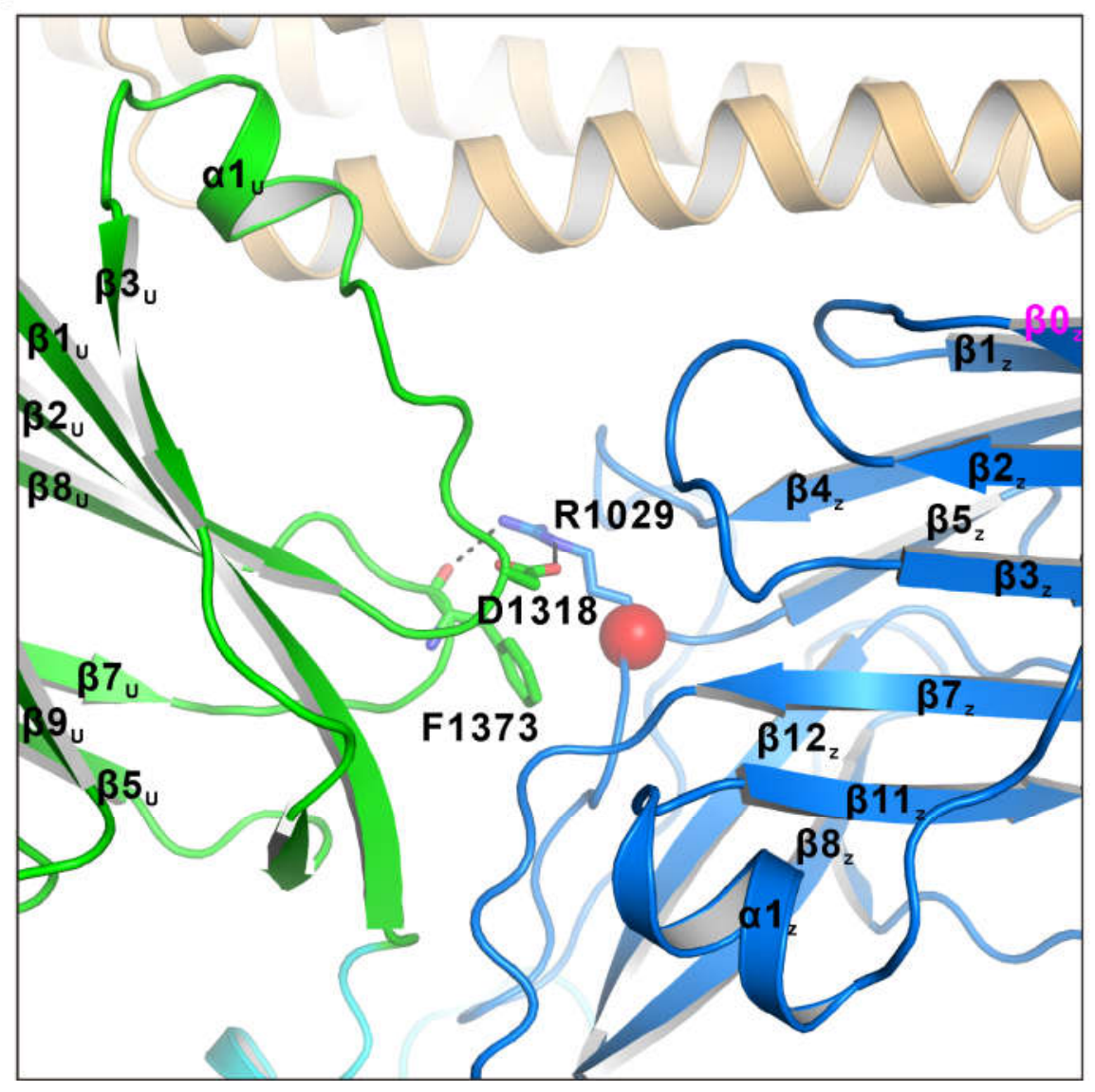

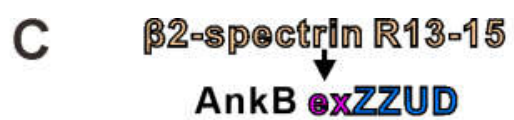

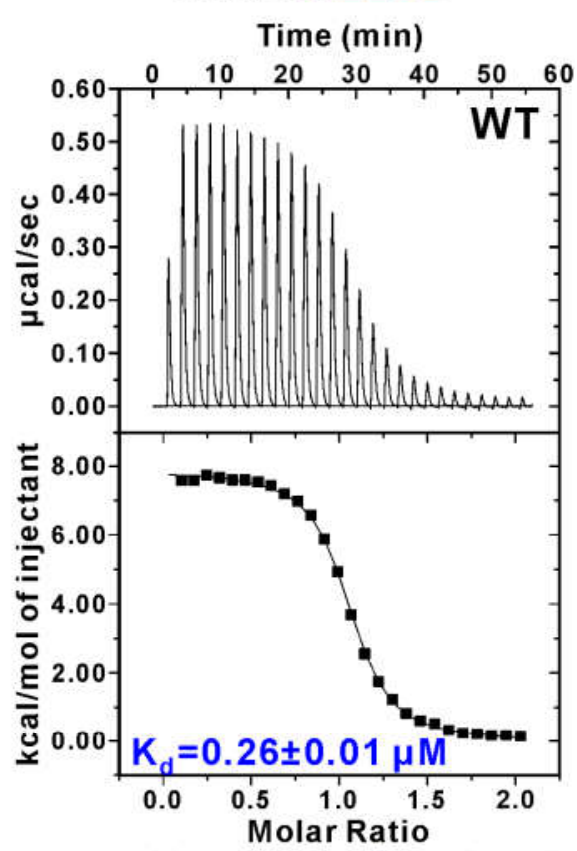

$\Delta \mathrm{H}=6.23 \pm 0.07 \mathrm{kcal} / \mathrm{mol}$ $\Delta \mathrm{S}=51.6 \mathrm{cal} /(\mathrm{mol} \cdot \mathrm{K})$

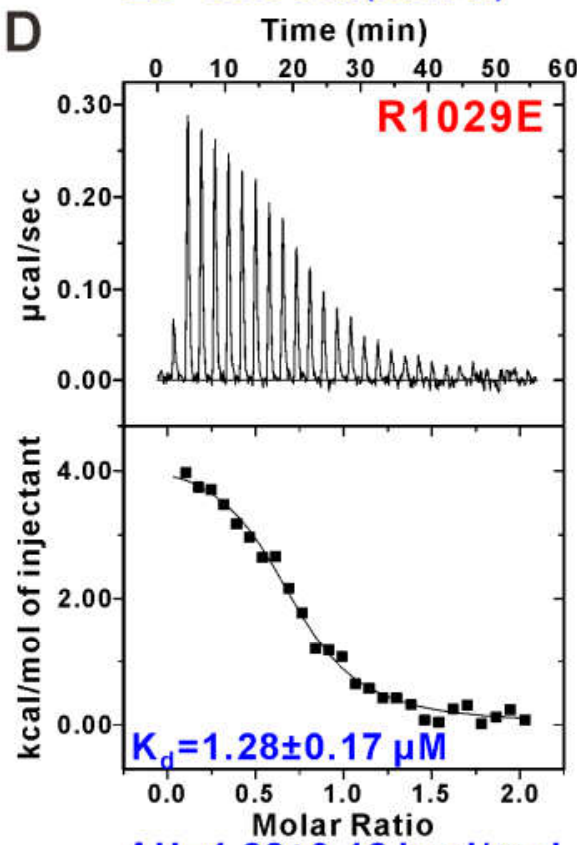

$\Delta \mathrm{H}=4.28 \pm 0.12 \mathrm{kcal} / \mathrm{mol}$

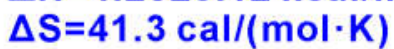




\section{Figure S1}

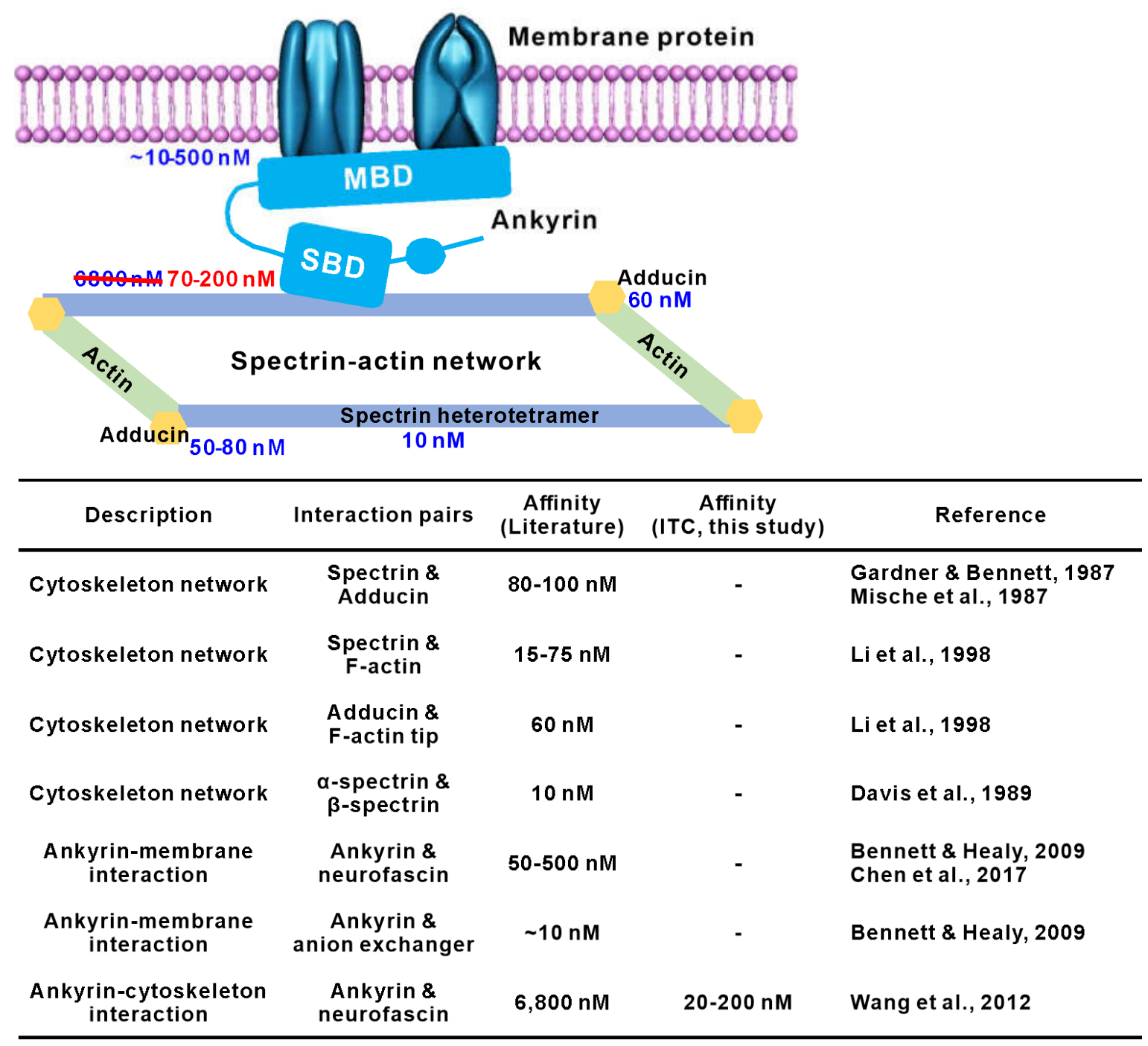


bioRxiv preprint doi: https://doi.org/10.1101/2020.03.04.976142. this version posted March 42020 . The copvriaht holder for this preprint (which was not certified by peer review) is the author/funder, who has granted bioRxiv a license to display the preprint in perpetuity. It is made available under aCC-BY-NC-ND 4.0 International license.

\section{Figure S2}

A
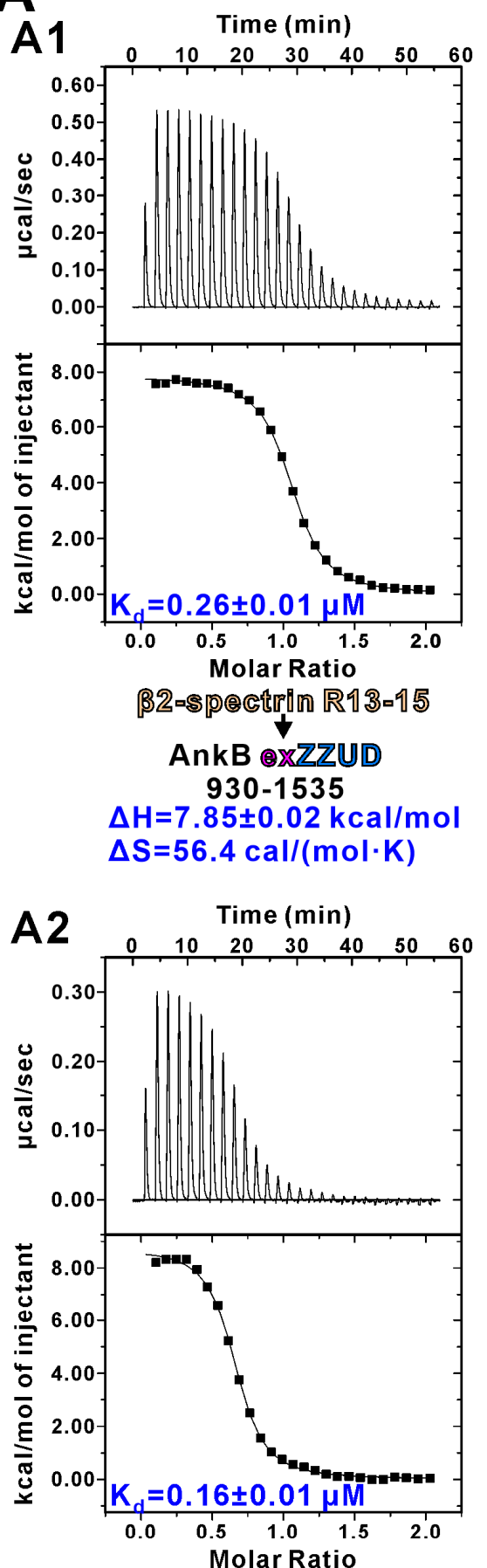

B2-8pectrin R14-15

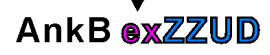

930-1535

$\Delta \mathrm{H}=8.74 \pm 0.06 \mathrm{kcal} / \mathrm{mol}$ $\Delta \mathrm{S}=60.4 \mathrm{cal} /(\mathrm{mol} \cdot \mathrm{K})$
B
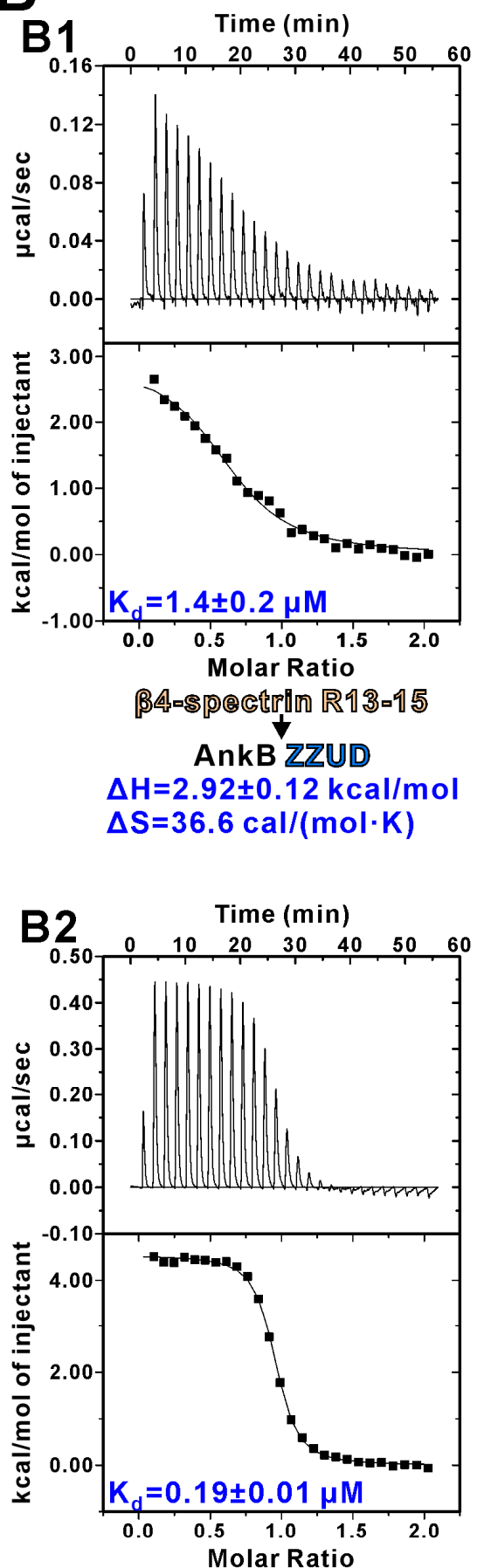

B4-Spectell R13-15

AnkB $\odot x \mathbb{Z} \cup \mathbb{D}$

$\Delta \mathrm{H}=4.54 \pm 0.02 \mathrm{kcal} / \mathrm{mol}$ $\Delta \mathrm{S}=46.0 \mathrm{cal} /(\mathrm{mol} \cdot \mathrm{K})$
C

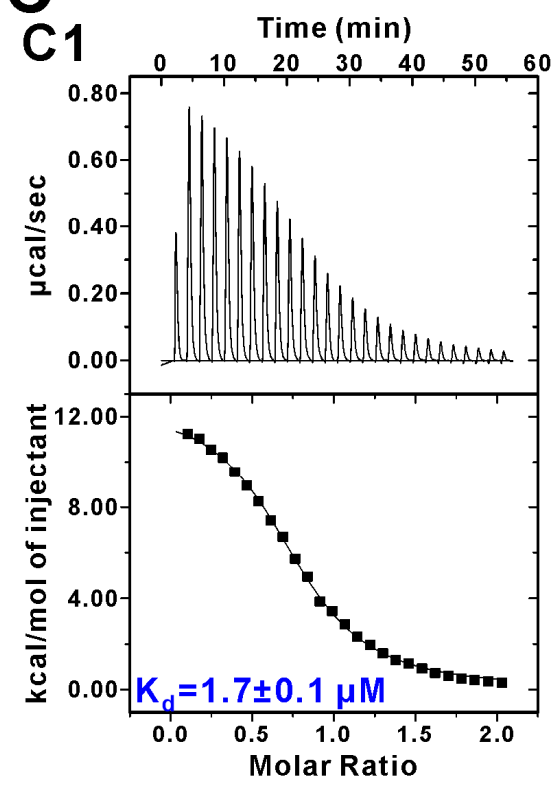

B1-Sp@etrll R13-1 R

AnkB $\mathbb{Z} Z \mathbb{Z}$ D

$\Delta \mathrm{H}=12.6 \pm 0.1 \mathrm{kcal} / \mathrm{mol}$

$\Delta \mathrm{S}=68.8 \mathrm{cal} /(\mathrm{mol} \cdot \mathrm{K})$

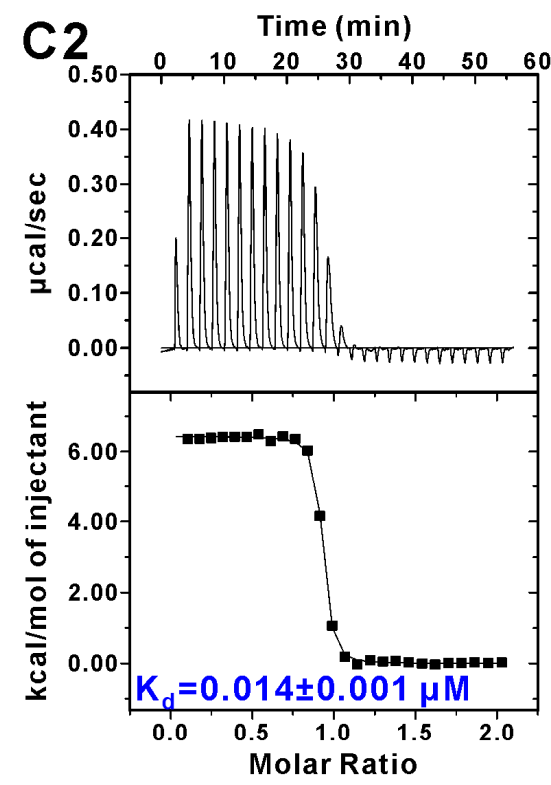

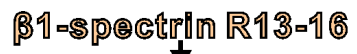

AnkB exZZZUD

884-1535

$\Delta \mathrm{H}=6.43 \pm 0.02 \mathrm{kcal} / \mathrm{mol}$ $\Delta \mathrm{S}=57.5 \mathrm{cal} /(\mathrm{mol} \cdot \mathrm{K})$ 
bioRxiv preprint doi: https://doi.org/10.1101/2020.03.04.976142; this version posted March 4, 2020. The copyright holder for this preprint (which was not certified by peer review) is the author/funder, who has granted bioRxiv a license to display the preprint in perpetuity. It is made available under aCC-BY-NC-ND 4.0 International license.

\section{Figure S3}

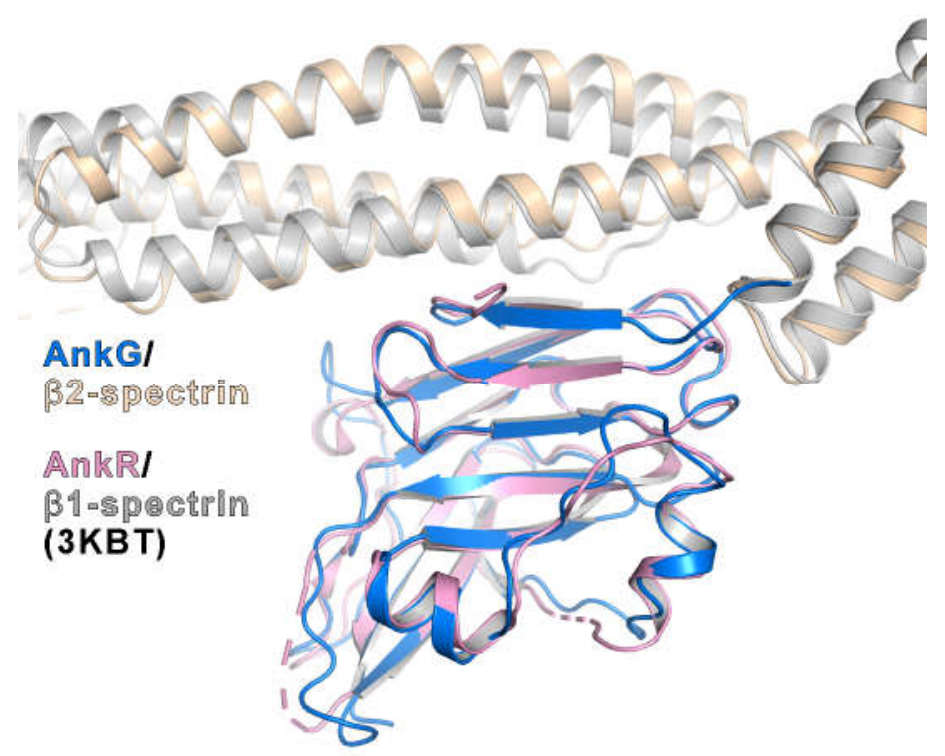

